\title{
Recent benthic foraminifera in the Arctic Ocean and Kara Sea continental margin
}

\author{
Katrine Husum $^{1} \cdot$ Morten Hald $^{2} \cdot$ Ruediger Stein $^{3} \cdot$ Monika Weißschnur $^{3}$
}

Received: 1 September 2015/Accepted: 16 October 2015/Published online: 20 November 2015

(C) Springer-Verlag Berlin Heidelberg 2015

\begin{abstract}
Living (stained) and dead (unstained) benthic foraminifera from the Arctic Ocean and Kara Sea continental margin have been investigated to extend the knowledge on modern living and dead benthic foraminifera in the Arctic Ocean. Three living and three dead benthic foraminiferal fauna assemblages have been distinguished based on Q-mode cluster analysis. In the seasonally icefree Nansen Basin, a living assemblage consisting of Ioanella tumidula-Stetsonia horvarthi assemblage has been established. On the permanently ice covered Lomonosov Ridge and Alpha Ridge in addition to the seasonally icefree Nansen Basin, the living assemblage is characterized by I. tumidula-Oridorsalis tener-S. horvarthi assemblage. The seasonally ice-free and relatively shallow Kara Sea continental margin displays a living fauna assemblage with agglutinated Reophax species in addition to the calcareous species Cassidulina neoteretis, Epistominella nipponica, and Islandiella helenae. The dead assemblages from Alpha Ridge, Lomonosov Ridge and Nansen Basin with assemblages characterized by I. tumidula, O. tener and S. horvathi reflect the living assemblages well. The dead fauna assemblage from the Kara Sea continental margin differs from the corresponding living assemblage by showing less agglutinated specimens and dominance by $C$. neoteretis. However, there is also a relatively good potential
\end{abstract}

Katrine Husum

katrine.husum@npolar.no

1 Norwegian Polar Institute, Fram Centre, 9296 Troms $\varnothing$, Norway

2 UiT-The Arctic University of Norway, 9037 Troms $\varnothing$, Norway

3 Alfred Wegener Institute (AWI) Helmholtz Centre for Polar and Marine Research, 27515 Bremerhaven, Germany reconstructing paleoenvironmental change from the Kara Sea continental margin, when it is taken into account that the agglutinated species are not well preserved in the dead assemblages.

Keywords Foraminifera - Environmental parameters . Modern distribution · Paleoceanography · Arctic Ocean · Kara Sea

\section{Introduction}

The Arctic Ocean is situated on top of the northern hemisphere and is the smallest ocean of the world oceans. Most of the Arctic Ocean is perennially covered by sea ice, and only minor areas are seasonally ice-free. During the winter, the region receives no sunlight and during summer, it is exposed to midnight sun. The Arctic Ocean is key component in the global climate-ocean system, as it is an oceanic gateway from the Pacific to the North Atlantic. However, our knowledge about this ocean in the past and present is still very limited due to the logistic challenges investigating this area. The need for knowledge is pressing as the Arctic Ocean and surrounding Arctic region, has undergone large changes last decades with reduction of sea ice and increasing temperatures of the inflowing water masses (e.g., [3, 42]). To understand the mechanisms and effects of this warming, it is crucial to obtain long records of the climate changes in the past to assess the natural limits of Arctic Ocean climate system. To obtain oceanographic data (e.g., on temperature, salinity, density, acidification, nutrition, etc.) in the water masses from the past when prior to instrumental measurements of these factors, we study micro-flora and micro-fauna in the sediments in addition to geochemical parameters. The fossil flora and 
fauna depends on environmental factors such as temperature and salinity of the seawater or nutrition, thus showing how the marine environment and water masses were back in time (paleoclimatic proxy data). Previous investigations of Quaternary sediments in the Arctic Ocean have shown that siliceous fossils as diatoms are poorly preserved (e.g., [6]). Further, some calcareous fossils as coccoliths are limited to certain time intervals. However, calcareous foraminifera appear more consistently throughout the Quaternary period (Darby et al. [6]) in this region and are considered one of the most useful proxy to reconstruct past ocean environments.

To understand the fossil foraminiferal record, it is necessary to understand the modern distribution patterns of the foraminifera in the Arctic Ocean. A limited amount of studies of benthic foraminifera in surface sediments in the Arctic Ocean and adjoining seas have been carried out the last forty years: Lagoe [21], Schröder-Adams et al. [37], Scott and Vilks [35], Bergsten [2], Hald and Steinsund [11], Ishman and Foley [15], Wollenburg and Mackensen [43], Osterman et al. [25], Wollenburg and Kuhnt [44], Scott et al. [36] and Saher et al. [30, 31]. Sediment samples investigated in these studies have been collected in different ways using grab samplers, gravity coring, box coring or multi coring. Thus, the quality of the surface sediments samples may vary, and some of the samples such as core tops from gravity cores and grab samples might not reflect the upper few centimeters of sea floor surface. Different size fractions have also been investigated in the previous studies of modern benthic foraminifera in the Arctic Ocean. Mainly, the $>63 \mu \mathrm{m}$ size fraction has been used analyzing benthic foraminifera [2, 21, 35, 37, 43, 44]. However, in paleoceanographic reconstructions from the Arctic Ocean, most studies have used $>125$ or $>150 \mu \mathrm{m}$ (e.g., [16, 17, 25, 29]). Additionally Wollenburg et al. [45] and Cronin et al. [5] used $>63 \mu \mathrm{m}$ size fraction. Staining of the living specimens has only been performed in some of the studies of modern benthic foraminifera: Schröder-Adams et al. [37], Bergsten [2], Hald and Steinsund [11], Wollenburg and Mackensen [43], Wollenburg and Kuhnt [44], Scott et al. [36] and Saher et al. [30, 31] Furthermore, only some of these studies have distinguished between stained (living) and not stained (dead) fauna assemblages counting at least 300 specimens from each group (e.g., Wollenburg and Mackensen [43], Wollenburg and Kuhnt [44]. The studies found that environmental parameters such as water depth, type of substrate and water mass characteristics are not the main factors ruling the distribution of modern benthic foraminifera. Some species and assemblages are, however, mainly controlled by food availability [43, 44].

The overall aim of this study is to extend the knowledge on modern benthic foraminifera in the Arctic Ocean distinguishing between living and dead fauna assemblages on the $>100 \mu \mathrm{m}$ size fraction.

\section{Study area}

Overall, the Arctic Ocean consists of two large basins; the Amerasian and Eurasian Basins which are separated by the Lomonosov Ridge reaching a maximum depth of ca 1870 m [19]. The Amundsen and Nansen Basins are found within the Eurasian Basin separated by the Gakkel Ridge (Figs. 1, 2). In the Amerasian Basin, an additional ridge, the Alpha Ridge is situated (Fig. 2). The basins are more than $3000 \mathrm{~m}$ deep. The Arctic Ocean is surrounded by shelf seas, and the Fram Strait is the only deep connection to the Arctic Ocean (e.g., [18]). The Arctic Ocean is perennially covered by sea ice except for large parts of the Fram Strait region and the southern Nansen Basin that are ice-free in summer (Fig. 1). This is due to the inflow of warm Atlantic water masses entering the Arctic Ocean through the Fram Strait and the Barents Sea (e.g., [1, 34]). There are generally three main water masses in the Arctic Ocean. The surface water masses that are homogenized during winter

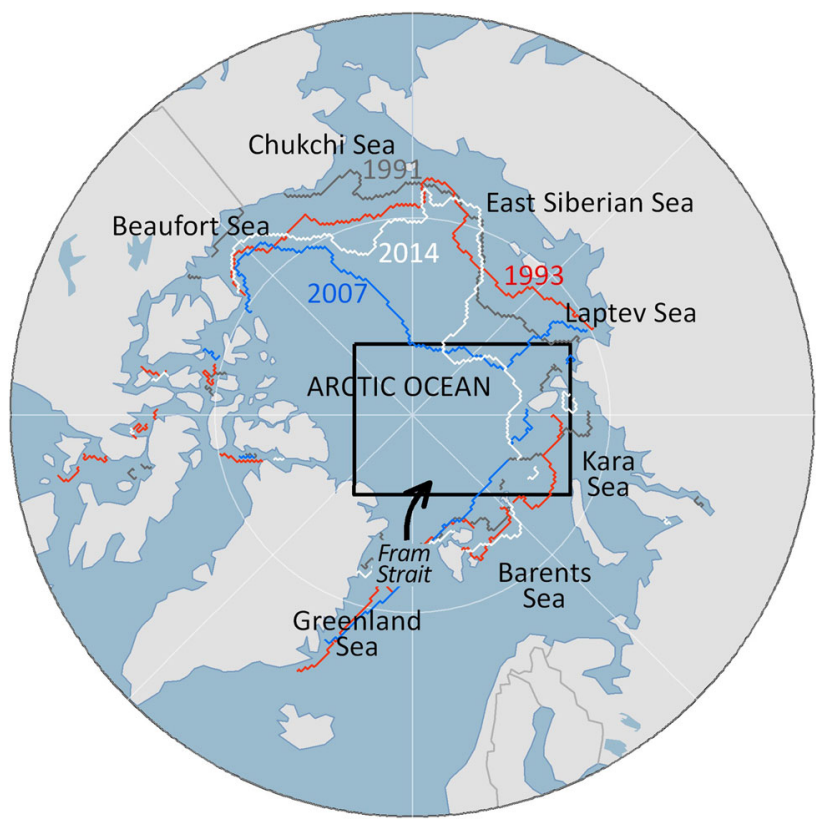

Fig. 1 Map of the Arctic Ocean and adjoining seas. Black square the investigation area that are shown in Figs. 2 and 5. Black arrow the inflow of Atlantic water to the Arctic Ocean. The sea ice extent in September from various years is also shown; 2014 (white line), 2007 (blue line), 1993 (red line), and 1991 (gray line). The sea ice extent is based on data from National Snow and Ice Data Center (NSIDC). These years were chosen as they are the sampling year of the current study (2007) and the sampling years $(1991,1993)$ of Wollenburg and Mackensen [43] 
Fig. 2 Bathymetric map showing the positions of the sampling stations in addition to the September sea ice extent from 2014 (white line), 2007 (blue line), 1993 (red line), and 1991 (gray line). The sea ice extent is based on data from National Snow and Ice Data Center (NSIDC)

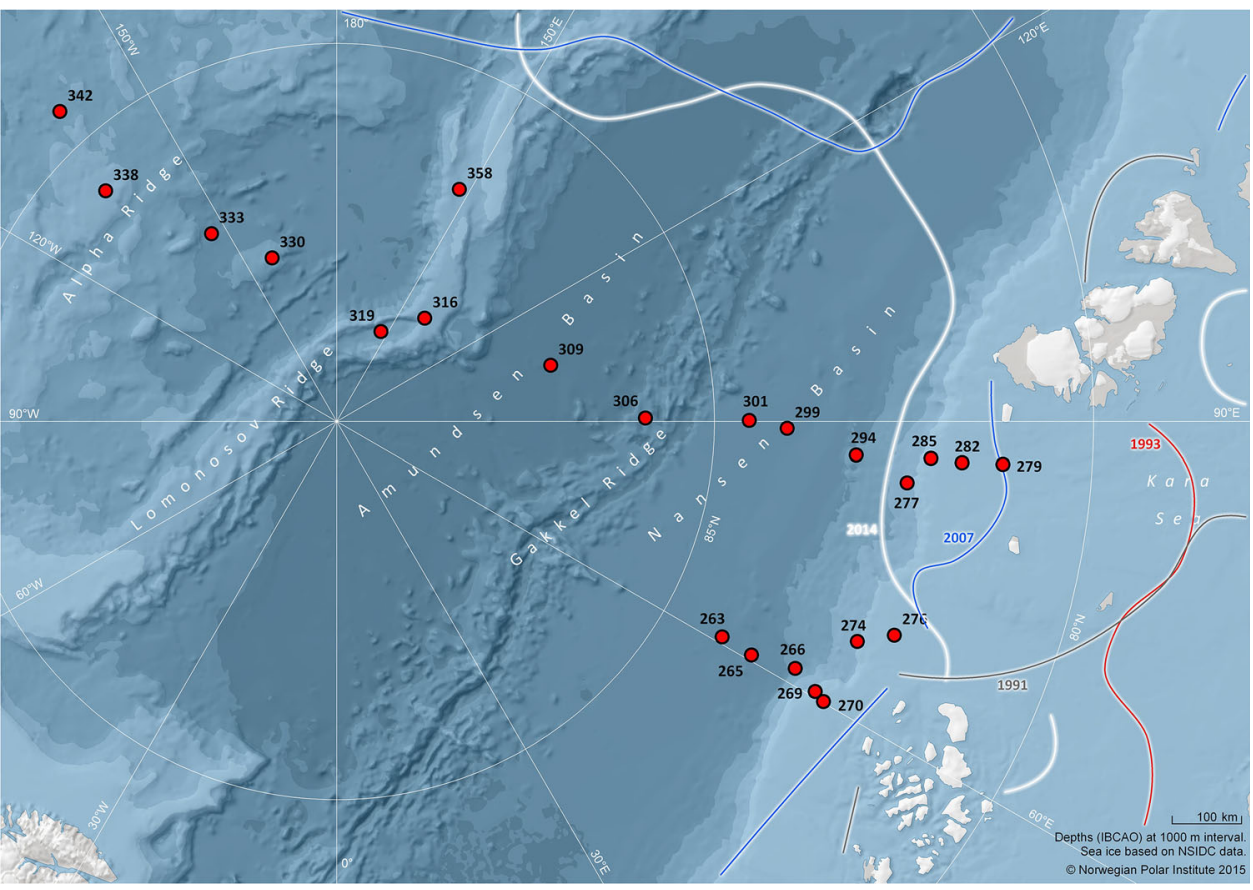

by freezing and brine release and during the summer are stratified by seasonal melt water (e.g., [26]). Below the surface water masses is the intermediate water masses of warmer and more saline Atlantic water. Underneath these water masses is the bottom waters in the basins [26]. The surface water masses are cold $\left(-2\right.$ to $\left.0{ }^{\circ} \mathrm{C}\right)$ and less saline (32-34 psu). The temperatures of the intermediate water masses are between 0 and $2{ }^{\circ} \mathrm{C}$ with a salinity from 34.7 to 35 psu [28]. The bottom water masses found deeper than $600-800 \mathrm{~m}$ show temperatures from -0.9 to $0{ }^{\circ} \mathrm{C}$ and a salinity around 34.9 psu [28].

\section{Materials and methods}

Twenty-three surface sediment samples were collected with RV "Polarstern" in August and September 2007 using a giant box corer during the ARK XXII-2 cruise in 2007 (Table 1). The upper $0-1 \mathrm{~cm}$ was sampled and preserved in unbuffered ethanol (96\%) with Rosa Bengal stain in cold storage for at least 14 days before further preparation. A separate bulk sample was also taken from the upper $0-1 \mathrm{~cm}$ of the box core to determine the content of organic (TOC) and total carbon $\left(\mathrm{CaCO}_{3}\right)$ in addition to grain size (Fig. 3). The samples were wet sieved at the $>1 \mathrm{~mm},>100$ and $>63 \mu \mathrm{m}$ size fractions and dried at room temperature for $24 \mathrm{~h}$. Only specimens with at least one clearly stained chamber were identified as stained specimens. The foraminiferal samples were counted at the size fraction $0.1-1.0 \mathrm{~mm}$ enabling direct comparisons with previous studies of recent foraminifera from Svalbard and the adjoining Barents Sea $[11,12,30]$ in addition to ensure a robust taxonomy which may be difficult to obtain using the $>63 \mu \mathrm{m}$ size fraction. At least 300 living specimens and at least 300 dead specimens were identified and counted for each sample. Both living and dead assemblages are presented to investigate the living foraminifera and their modern environmental preferences in addition to identify any post-mortem changes of the fauna. In samples where it was not possible to obtain 300 specimens, only samples containing at least 100 living or 100 dead specimens were included when calculating relative and quantitative abundances (Appendix 1). Only species constituting at least $1 \%$ of the total fauna in at least two samples were included in an unweighted pair-group average R-mode clustering analysis using Euclidean distance (Fig. 4). The species diversity was investigated using the Fisher alpha diversity index [9] in addition to the Shannon-Wiener diversity index $\mathrm{H}(\mathrm{S})[14,38])$. The cluster analysis and calculation of the diversity indices were carried out using the PAST software, version 2.17c [13].

\section{Results}

\section{Surface sediments}

The sediment samples consist of mainly clay and silt that constitute an average value of $90 \%$ (Fig. 3). Two stations from Alpha Ridge $(338,342)$ differ from the others containing, respectively, 65 and $62 \%$ clay and silt. The sampling stations differ with regard to the content of 
Table 1 List of the stations and their geographical coordinates and water depth in addition to the bottom water temperature and salinity [33]

\begin{tabular}{|c|c|c|c|c|c|c|c|c|}
\hline Area & St. & Latitude & Longitude & $\begin{array}{l}\text { Water } \\
\text { depth (m) }\end{array}$ & $\begin{array}{l}\text { Bottom water } \\
\text { temp }\left({ }^{\circ} \mathrm{C}\right)\end{array}$ & $\begin{array}{l}\text { Salinity } \\
\text { (psu) }\end{array}$ & LFA & DFA \\
\hline Nansen Basin & 263 & $84^{\circ} 09.45^{\prime} \mathrm{N}$ & $60^{\circ} 51.42^{\prime} \mathrm{E}$ & 3700 & -0.9 & 34.9 & 1 & 2 \\
\hline Nansen Basin & 265 & $83^{\circ} 42.17 \mathrm{~N}$ & $60^{\circ} 39.26^{\prime} \mathrm{E}$ & 3538 & No data & No data & 1 & 2 \\
\hline Nansen Basin & 266 & $83^{\circ} 06.62^{\prime} \mathrm{N}$ & $61^{\circ} 43.92^{\prime} \mathrm{E}$ & 2995 & -0.9 & 34.9 & 1 & Outlier \\
\hline Kara Sea continental margin & 269 & $82^{\circ} 44.01^{\prime} \mathrm{N}$ & $60^{\circ} 35.96^{\prime} \mathrm{E}$ & 864.1 & 0.7 & 34.9 & 3 & 3 \\
\hline Kara Sea continental margin & 270 & $82^{\circ} 34.45^{\prime} \mathrm{N}$ & $60^{\circ} 06.78^{\prime} \mathrm{E}$ & 324.9 & 0.3 & 34.9 & 3 & 3 \\
\hline Kara Sea continental margin & 274 & $82^{\circ} 31.54^{\prime} \mathrm{N}$ & $67^{\circ} 07.18^{\prime} \mathrm{E}$ & 1187 & -0.5 & 34.9 & 3 & 3 \\
\hline Kara Sea continental margin & 276 & $82^{\circ} 06.18^{\prime} \mathrm{N}$ & $69^{\circ} 04.00^{\prime} \mathrm{E}$ & 686.9 & 0.3 & 34.9 & Outlier & 3 \\
\hline Kara Sea continental margin & 277 & $82^{\circ} 24.57^{\prime} \mathrm{N}$ & $83^{\circ} 52.21^{\prime} \mathrm{E}$ & 1564 & -0.7 & 34.9 & Outlier & Outlier \\
\hline Kara Sea continental margin & 279 & $81^{\circ} 10.38^{\prime} \mathrm{N}$ & $86^{\circ} 18.98^{\prime} \mathrm{E}$ & 309.4 & -0.4 & 34.9 & 3 & 3 \\
\hline Kara Sea continental margin & 282 & $81^{\circ} 42.72^{\prime} \mathrm{N}$ & $86^{\circ} 13.68^{\prime} \mathrm{E}$ & 361.9 & -0.4 & 34.9 & 3 & 3 \\
\hline Kara Sea continental margin & 285 & $82^{\circ} 07.47^{\prime} \mathrm{N}$ & $86^{\circ} 27.05^{\prime} \mathrm{E}$ & 677.2 & -0.4 & 34.9 & 3 & 3 \\
\hline Nansen Basin & 294 & $83^{\circ} 06.65^{\prime} \mathrm{N}$ & $86^{\circ} 17.95^{\prime} \mathrm{E}$ & 3148 & -0.9 & 34.9 & 1 & 2 \\
\hline Nansen Basin & 299 & $84^{\circ} 02.22^{\prime} \mathrm{N}$ & $89^{\circ} 06.07^{\prime} \mathrm{E}$ & 3696 & -0.9 & 34.9 & 2 & 2 \\
\hline Nansen Basin & 301 & $84^{\circ} 32.31^{\prime} \mathrm{N}$ & $90^{\circ} 07.17^{\prime} \mathrm{E}$ & 3762 & -0.9 & 34.9 & 2 & 2 \\
\hline Gakkel Ridge & 306 & $85^{\circ} 54.71^{\prime} \mathrm{N}$ & $90^{\circ} 36.13^{\prime} \mathrm{E}$ & 4079 & -0.9 & 34.9 & $\mathrm{Na}$ & $\mathrm{Na}$ \\
\hline Amundsen Basin & 309 & $87^{\circ} 04.18^{\prime} \mathrm{N}$ & $104^{\circ} 39.56^{\prime} \mathrm{E}$ & 4443 & -0.9 & 34.9 & Outlier & 2 \\
\hline Lomonosov Ridge & 316 & $88^{\circ} 12.24^{\prime} \mathrm{N}$ & $139^{\circ} 27.58^{\prime} \mathrm{E}$ & 1335 & -0.4 & 34.9 & 2 & 1 \\
\hline Lomonosov Ridge & 319 & $88^{\circ} 40.51^{\prime} \mathrm{N}$ & $153^{\circ} 44.06^{\prime} \mathrm{E}$ & 2746 & -0.7 & 34.9 & 2 & Outlier \\
\hline Alpha Ridge & 330 & $87^{\circ} 40.49^{\prime} \mathrm{N}$ & $158^{\circ} 26.95^{\prime} \mathrm{W}$ & 2460 & No data & No data & 2 & 1 \\
\hline Alpha Ridge & 333 & $87^{\circ} 00.82^{\prime} \mathrm{N}$ & $146^{\circ} 17.49^{\prime} \mathrm{W}$ & 3368 & -0.5 & 34.9 & Outlier & 1 \\
\hline Alpha Ridge & 338 & $85^{\circ} 40.92^{\prime} \mathrm{N}$ & $134^{\circ} 54.90^{\prime} \mathrm{W}$ & 1567 & -0.5 & 34.9 & $\mathrm{Na}$ & 1 \\
\hline Alpha Ridge & 342 & $84^{\circ} 30.24^{\prime} \mathrm{N}$ & $138^{\circ} 12.84^{\prime} \mathrm{W}$ & 2262 & -0.5 & 34.9 & $\mathrm{Na}$ & 1 \\
\hline Lomonosov Ridge & 358 & $86^{\circ} 31.54^{\prime} \mathrm{N}$ & $152^{\circ} 05.98^{\prime} \mathrm{E}$ & 1467 & -0.4 & 34.9 & 2 & 1 \\
\hline
\end{tabular}

It is also shown which assemblages the station belongs to (LFA/DFA)

$\mathrm{Na}$ not applicable due to too few specimens

$\mathrm{CaCO}_{3}$ that fluctuates between 1 and $24 \%$ (Fig. 3). The highest values from 14 to $24 \%$ are found on Alpha Ridge (stations 330, 333, 338, 342). The other sampling stations show variating values regardless of the water depths. The content of total organic carbon (TOC) is between 0.2 and $1.4 \%$. The sampling stations show an overall trend of decreasing TOC values from the Kara Sea Shelf across the Nansen and Amundsen Basins towards the Alpha Ridge (Fig. 3). The stations on Alpha Ridge show the lowest values of TOC found in this study $(0.2-0.4 \%)$.

\section{Foraminifera}

Twenty-three samples were analyzed with regard to living and benthic foraminifera. Three sampling stations contained less than 100 living (stained) specimens, but all sampling stations except St. 306 contained more than 100 dead specimens (Appendix 1). The living fauna showed 5-38 species and the dead fauna 8-41 species (Table 2). The benthic foraminiferal concentration varies from 61 to 1274 specimens $/ 10 \mathrm{~cm}^{3}$ sediment for the living fauna to
$225-21030 \mathrm{spec} . / 10 \mathrm{~cm}^{3}$ sed. for the dead fauna (Table 2). Three living and three dead fauna assemblages were identified using cluster analysis (Fig. 4). The clusters of living and dead assemblages are relatively similar, yet with some differences. The living fauna assemblages encompass larger geographical areas, whereas the dead fauna assemblages are more restricted (Fig. 5).

\section{Living fauna}

The cluster analysis of the living benthic foraminiferal fauna recognized three clusters and four outliers (Figs. 4a, 5a). The first cluster (1) consists of four stations from the Nansen Basin (stations 263, 265, 266 and 294), The cluster (1) is dominated by Ioanella tumidula with up to $39 \%$ (Fig. 6a). Other frequent species with more than $10 \%$ abundance are Stetsonia horvathi, Reophax fusiformis and Jaculella sp. (Fig. 6a; Appendix 1). Cluster 1 contains between 14 and 23 species. The diversity indices Fisher alpha and $\mathrm{H}(\mathrm{S})$ are between $4-10$ and 2, respectively (Table 2). Cluster 2 is found in Nansen Basin and on the Alpha Ridge in addition to 


\section{Clay and silt (\%)}

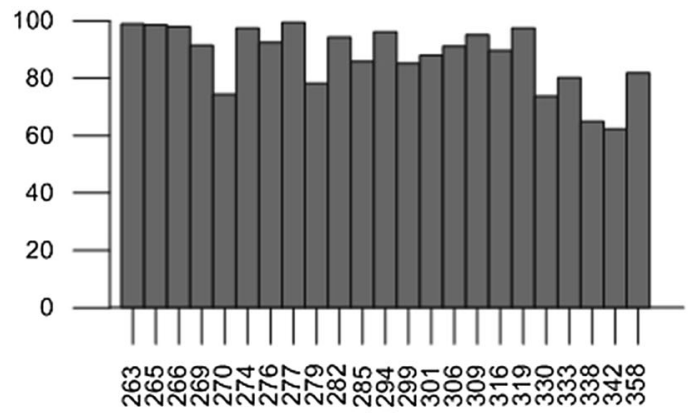

TOC (\%)
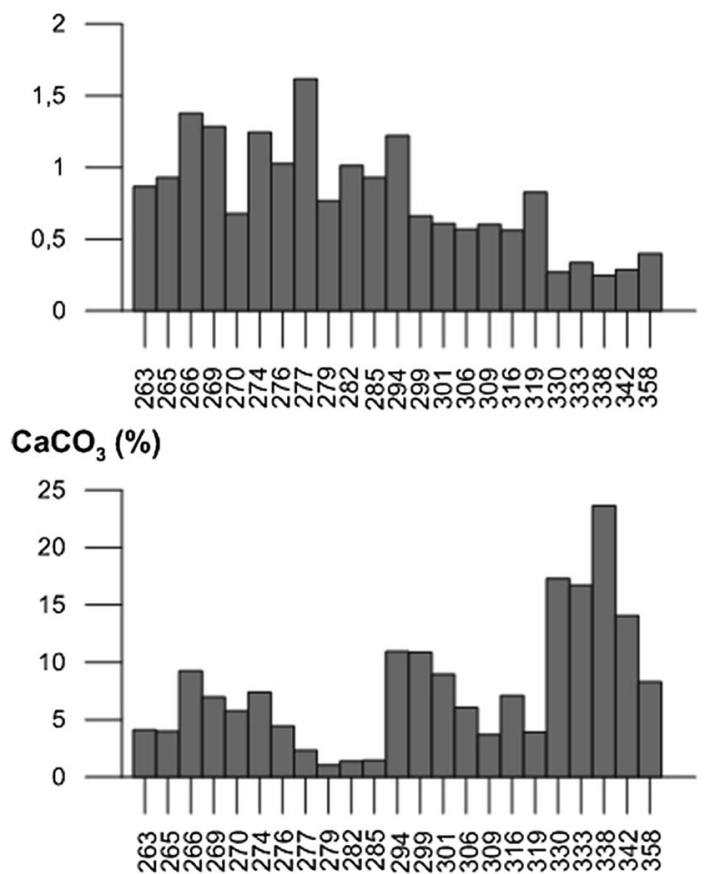

Fig. 3 Sedimentological parameters

Lomonosov Ridge (stations 299, 301, 316, 319, 330, 358). This cluster is heavily dominated of I. tumidula (38-68\%). Oridorsalis tener constitutes between 2 and $23 \%$, whereas S. horvathi constitutes zero to $13 \%$ (Fig. 6a). The number of species is $5-16$. Fisher alpha is $1-5$ and $\mathrm{H}(\mathrm{S})$ is 1 (Table 2). One outlier is found in Amundsen Basin, station 309, and is characterized by Aschemonella sp. 1 (Fig. 4a; Appendix 1). The fourth outlier is found on Alpha Ridge (station 333) and is dominated by I. tumidula and O. tener. Cluster 3 contains 6 stations from the Kara Sea continental margin (stations 269, 270, 274, 279, 282, 285). Cluster 3 differs from cluster 1 by being dominated by Reophax spp. which variates between 6 and $34 \%$ (Figs. 4a, 6b). R. guttifer and Sacamminna atlantica are also abundant with average frequencies around $4 \%$. C. neoteretis also characterizes cluster 3 with an average abundance around $7 \%$ (Fig. 6a). Other characteristic calcareous species are Epistominella nipponica and Islandiella helenae with average abundances between 3 and $4 \%$

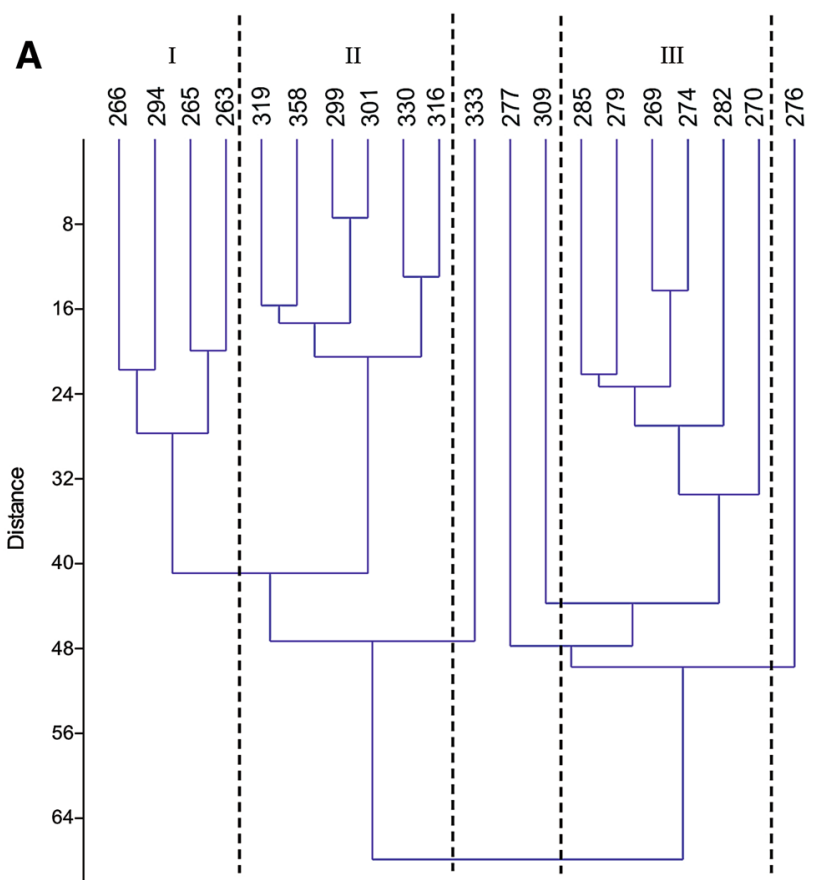

B

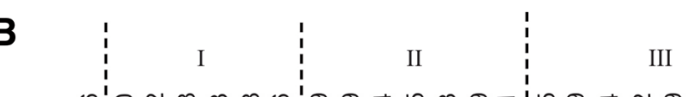

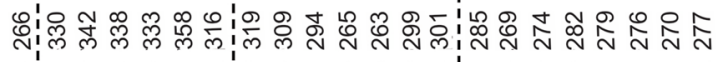

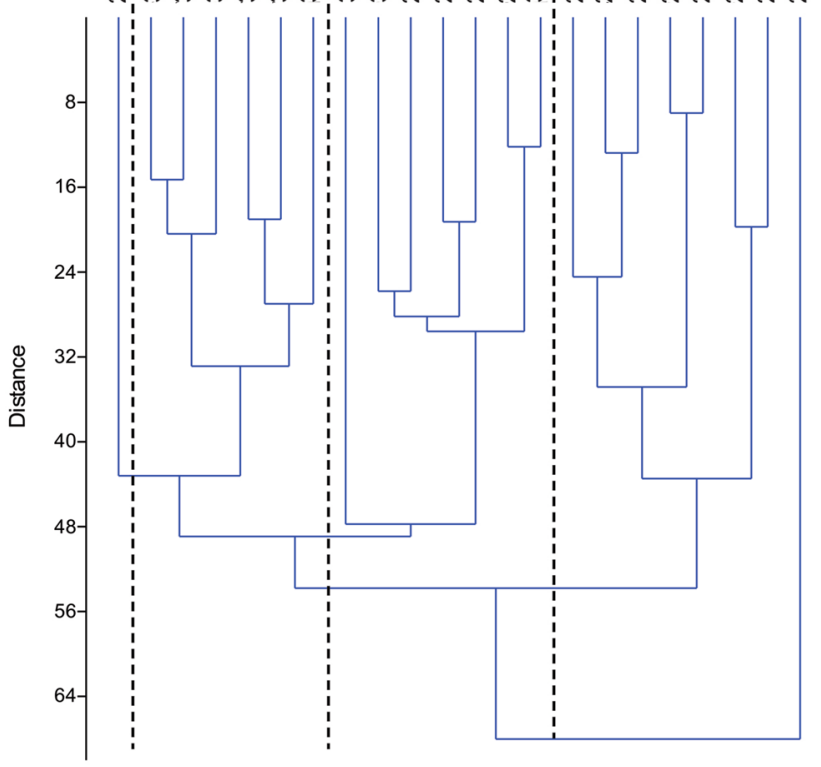

Fig. 4 a Q-mode cluster analysis of the living fauna assemblages. The numbers on the $x$ axis are referring to the station numbers, and the roman numbers $(I, I I, I I)$ refer to the cluster. The samples outside the clusters are outliers. b Q-mode cluster analysis of the dead fauna assemblages. The numbers on the $x$ axis are referring to the station numbers, and the roman numbers $(I, I I, I I)$ refer to the cluster. The samples outside the clusters are outliers

(Appendix 1). The diversity indices are different from cluster 1 by a higher number of species (28-38). The diversity indices also increase to $13-24$ for Fisher alpha and 2-3 for 
Table 2 Overview of benthic foraminiferal concentration (specimens $/ 10 \mathrm{~cm}^{3}$ ), number of species and the diversity indices Fisher alpha and $\mathrm{H}(\mathrm{S})$ for each sample (both living and dead assemblages)

\begin{tabular}{|c|c|c|c|c|c|c|c|c|c|}
\hline \multirow[t]{2}{*}{ Area } & \multirow[t]{2}{*}{ St. } & \multicolumn{4}{|l|}{ Living } & \multicolumn{4}{|l|}{ Dead } \\
\hline & & Spec. $/ 10 \mathrm{~cm}^{3}$ & $\begin{array}{l}\text { No. of } \\
\text { species }\end{array}$ & $\begin{array}{l}\text { Fisher } \\
\text { alpha }\end{array}$ & $\mathrm{H}(\mathrm{S})$ & Spec. $/ 10 \mathrm{~cm}^{3}$ & $\begin{array}{l}\text { No. of } \\
\text { species }\end{array}$ & $\begin{array}{l}\text { Fisher } \\
\text { alpha }\end{array}$ & $\mathrm{H}(\mathrm{S})$ \\
\hline Nansen Basin & 263 & 126 & 18 & 6 & 2 & 326 & 27 & 12 & 2 \\
\hline Nansen Basin & 265 & 61 & 14 & 4 & 2 & 534 & 20 & 8 & 2 \\
\hline Nansen Basin & 266 & 120 & 17 & 6 & 2 & 225 & 20 & 8 & 2 \\
\hline Kara Sea continental margin & 269 & 459 & 32 & 17 & 3 & 3238 & 35 & 24 & 3 \\
\hline Kara Sea continental margin & 270 & 1274 & 30 & 16 & 3 & 21,030 & 41 & 29 & 2 \\
\hline Kara Sea continental margin & 274 & 173 & 38 & 24 & 3 & 1656 & 36 & 22 & 2 \\
\hline Kara Sea continental margin & 276 & 124 & 12 & 4 & 2 & 1100 & 11 & 3 & 2 \\
\hline Kara Sea continental margin & 277 & 466 & 24 & 10 & 2 & 460 & 22 & 9 & 2 \\
\hline Kara Sea continental margin & 279 & 254 & 30 & 16 & 3 & 968 & 34 & 19 & 3 \\
\hline Kara Sea continental margin & 282 & 177 & 28 & 15 & 3 & 374 & 33 & 18 & 3 \\
\hline Kara Sea continental margin & 285 & 680 & 28 & 13 & 2 & 1472 & 34 & 20 & 3 \\
\hline Nansen Basin & 294 & 154 & 23 & 10 & 2 & 762 & 25 & 12 & 3 \\
\hline Nansen Basin & 299 & 130 & 11 & 3 & 1 & 1269 & 28 & 13 & 2 \\
\hline Nansen Basin & 301 & 212 & 10 & 3 & 1 & 1257 & 21 & 8 & 2 \\
\hline Gakkel Ridge & 306 & 4 & $\mathrm{Na}$ & $\mathrm{Na}$ & $\mathrm{Na}$ & 140 & $\mathrm{Na}$ & $\mathrm{Na}$ & $\mathrm{Na}$ \\
\hline Amundsen Basin & 309 & 65 & 17 & 6 & 2 & 272 & 18 & 7 & 2 \\
\hline Lomonosov Ridge & 316 & 465 & 13 & 4 & 1 & 1311 & 25 & 11 & 3 \\
\hline Lomonosov Ridge & 319 & 140 & 16 & 5 & 1 & 512 & 23 & 10 & 2 \\
\hline Alpha Ridge & 330 & 187 & 5 & 1 & 1 & 6528 & 14 & 5 & 2 \\
\hline Alpha Ridge & 333 & 111 & 11 & 3 & 1 & 1018 & 16 & 5 & 2 \\
\hline Alpha Ridge & 338 & 24 & $\mathrm{Na}$ & $\mathrm{Na}$ & $\mathrm{Na}$ & 2703 & 8 & 2 & 1 \\
\hline Alpha Ridge & 342 & 0 & $\mathrm{Na}$ & $\mathrm{Na}$ & $\mathrm{Na}$ & 1437 & 10 & 3 & 1 \\
\hline Lomonosov Ridge & 358 & 259 & 8 & 2 & 1 & 2208 & 14 & 4 & 2 \\
\hline
\end{tabular}

$\mathrm{Na}$ not applicable due to too few specimens

$\mathrm{H}(\mathrm{S})$ (Table 2). The remaining two stations from the Kara Sea Margin (stations 276 and 277) were identified as outliers (Fig. 4a), and they are each strongly dominated by two different species: Cassidulina neoteretis (40\%) and Hormosinella guttifera (41\%).

\section{Dead fauna}

Three clusters and three outliers were identified when the cluster analysis was performed on the dead benthic foraminiferal fauna (Figs. 4b, 5b). Cluster 1 includes only stations from the Lomonosov Ridge and Alpha Ridge (stations 316, 330, 333, 338, 342, and 358). Cluster 1 is distinguished by $I$. tumidula and $O$. tener with average abundances of 28 and $26 \%$ (Fig. 6a). Cibicides wuellerstorfi is also very frequent with $2-30 \%$. The number of species varies between 8 and 25. Fisher alpha and $H(S)$ are 2-11 and 1-3. An outlier, station 319, is situated on Lomonosov Ridge and is dominated by Epistominella arctica. The next cluster (2) includes the stations from
Nansen Basin and Amundsen Basin (stations 263, 265, 294, 299, 301, and 309). This cluster (2) is characterized by $S$. horvathi (17-34\%) in addition to I. tumidula and Triloculina frigida that both occur with an average abundance of $9 \%$ (Figs. 4a, 6a). Different Aschemonella species are also relatively frequent in this cluster. The number of species varies from 20 to 27 . Fisher alpha is $7-12$ and $H(S)$ is $2-3$. The outliers from the Kara Sea continental margin (stations 266 and 277) are dominated by Adercotryma glomeratum and R. guttifer (Fig. 6b). The last cluster (3) is restricted to stations on the Kara Sea continental margin (stations 269, 270, 274, 276, 279, 282, 285). This cluster is mainly dominated by $C$. neoteretis with an average frequency around $29 \%$. The cluster is also defined by $R$. guttifer and S. atlantica with average abundances of 10 and $6 \%$ (Fig. 6a, b). Another frequent species are Placopsilinella aurantiaca, I. helenae and Reophax spp. reaching up to 8, 9 and $17 \%$, respectively. This cluster (3) is also characterized by 11-41 species. The diversity indices Fisher alpha and $H(S)$ are 3-29 and 2-3, respectively (Table 2). 
Fig. 5 a Bathymetric map showing the positions of the sampling stations and indicating which clusters they belong to (living fauna assemblages). Red circles the stations that were not included in the cluster analysis due to too few specimens $(<100$ specimens). Black filled circles the outliers. Triangles living foraminiferal (LF) assemblage LFA1; filled squares assemblage LFA2; asterisks assemblage LFA3. September sea ice extent from 2014 (white line), 2007 (blue line), 1993 (red line), and 1991 (gray line) are also shown. The sea ice extent is based on data from National Snow and Ice Data Center (NSIDC). b Bathymetric map showing the positions of the sampling stations and indicating which clusters they belong to (dead fauna assemblages). Red circle the station that was not included in the cluster analysis due to too few specimens $(<100$ specimens). Black filled circles the outliers. Filled squares dead foraminiferal (DF) assemblage DFA1; triangles assemblage DFA2; asterisks assemblage DFA3. September sea ice extent from 2014 (white line), 2007 (blue line), 1993 (red line), and 1991 (gray line) are also shown. The sea ice extent is based on data from National Snow and Ice Data Center (NSIDC)
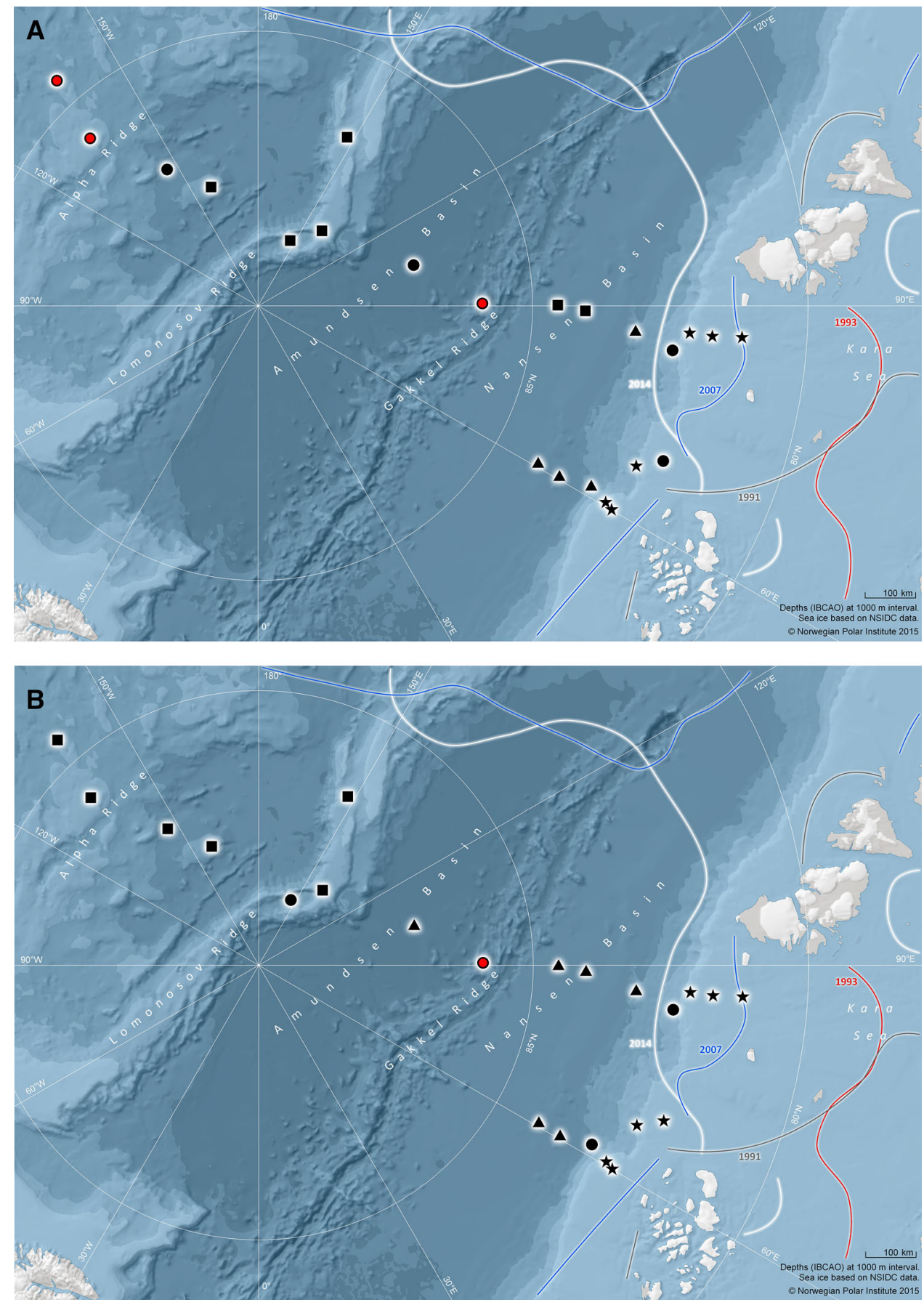

\section{Discussion}

Three living fauna assemblages (LFA1, 2, 3) and three dead fauna assemblages (DFA1, 2, 3) have been identified. In this paragraph, the distribution of living fauna assemblages will be discussed with regard to the modern environmental parameters, and the dead fauna assemblages will be compared to the living assemblages discussing their potential use in paleoceanographic reconstructions.

\section{Living fauna assemblages and modern environmental parameters}

The bottom water temperature at the sampling stations varies between -0.9 and $-0.4{ }^{\circ} \mathrm{C}$, except one measurement from the Kara Sea continental shelf at $0.7^{\circ} \mathrm{C}$ (Table 1). The salinity of the bottom water masses is very stable at 34.9 psu for all stations. Hence, the different fauna assemblages, with the Kara Sea continental shelf as a 
Fig. 6 a The relative abundance of the most frequent calcareous species living and dead. The selected species occur with $10 \%$ in at least two stations. b The relative abundance of the most frequent agglutinated species living and dead. The selected species occur with $10 \%$ in at least two stations
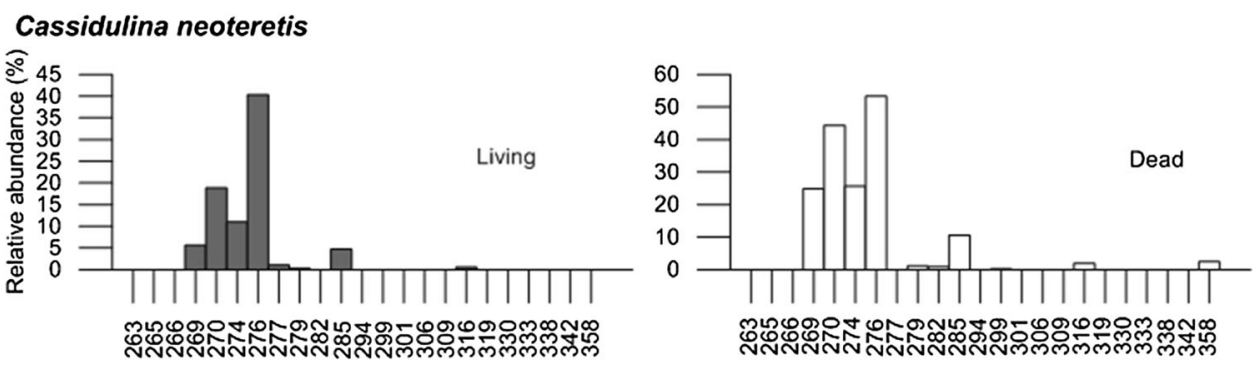

\section{Cibicides wuellerstorfi}

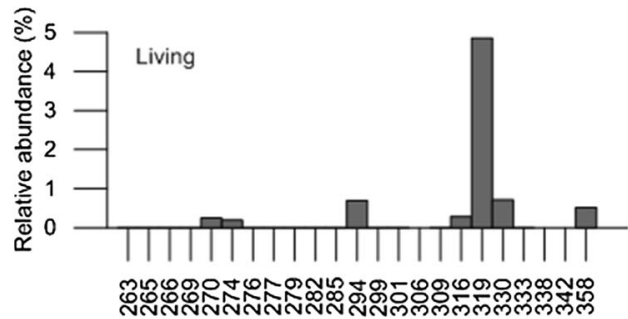

Eponides tumidulus
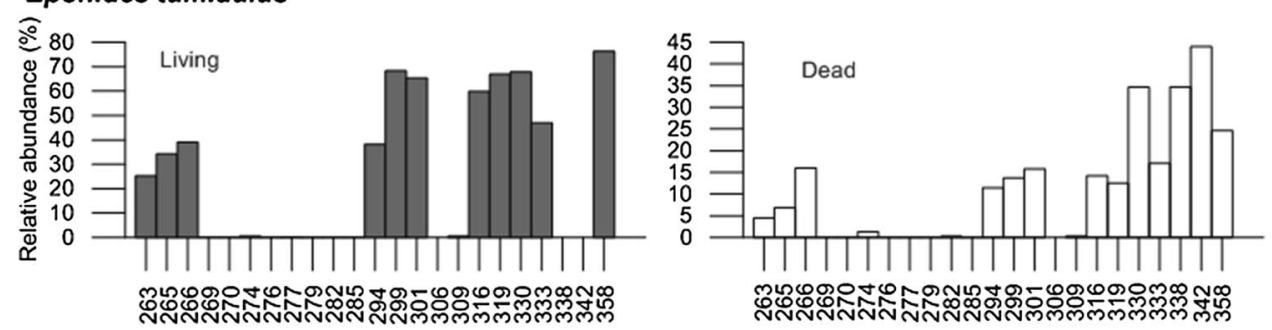

Oridorsalis tener
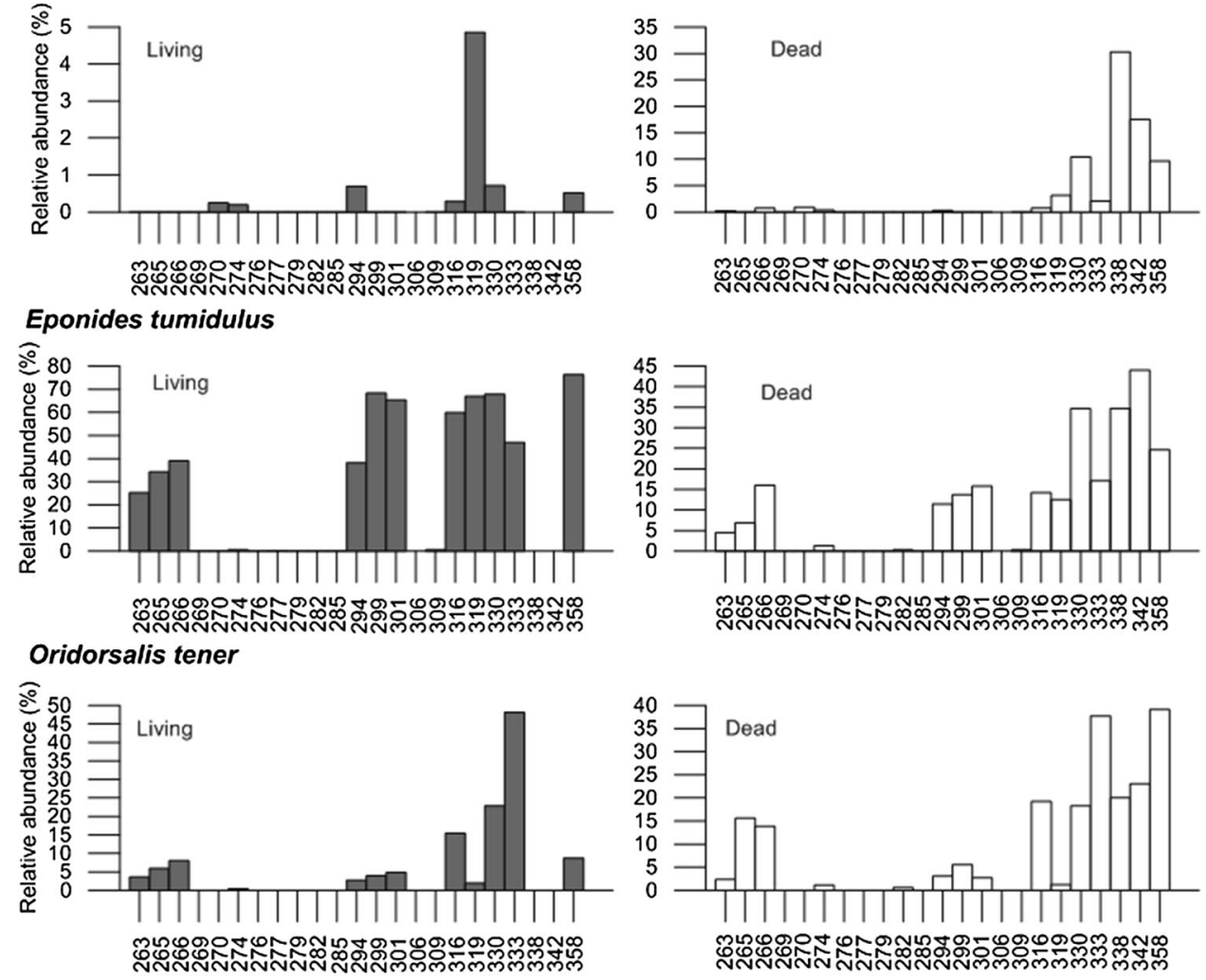

Stetsonia horvathi
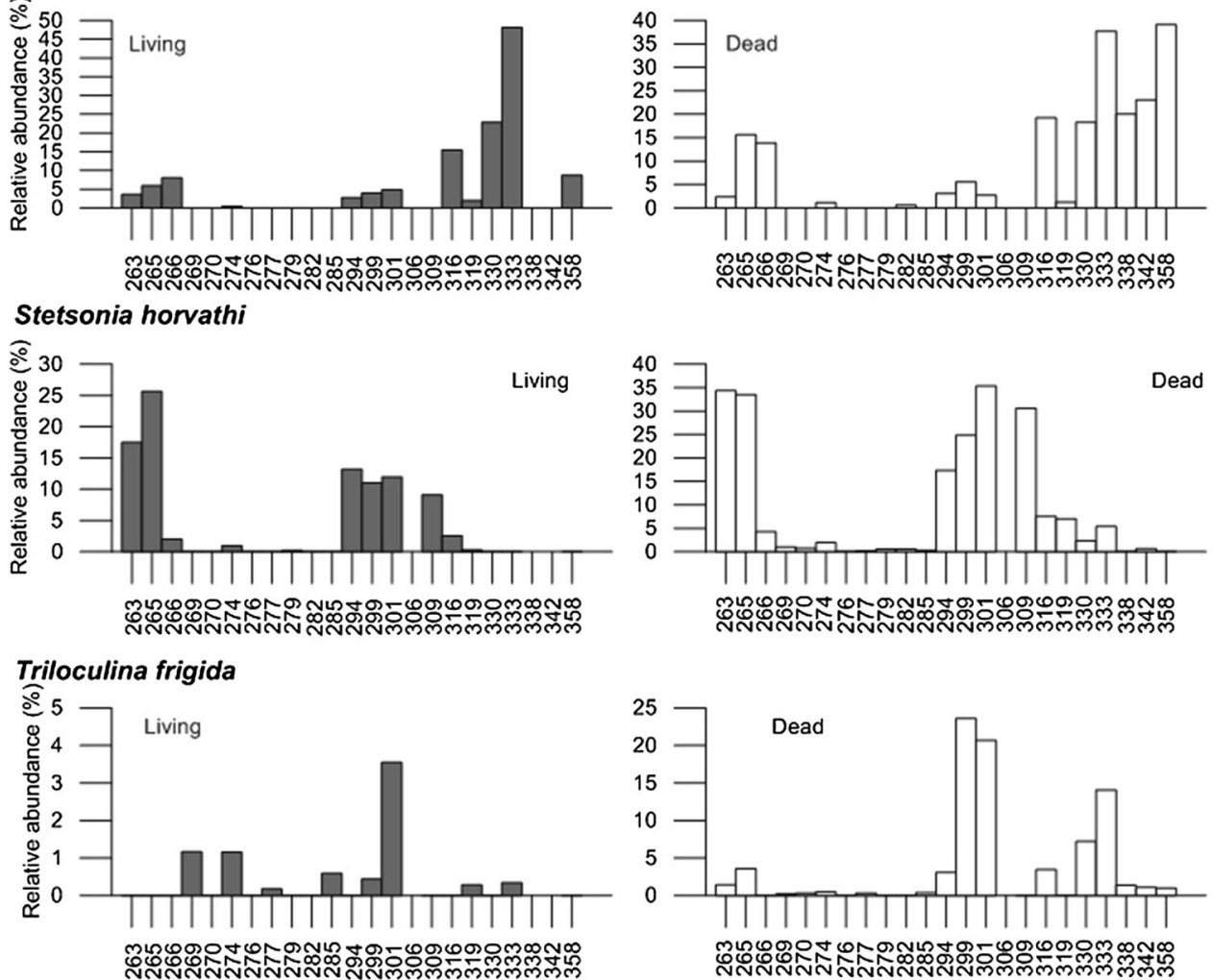
Fig. 6 continued
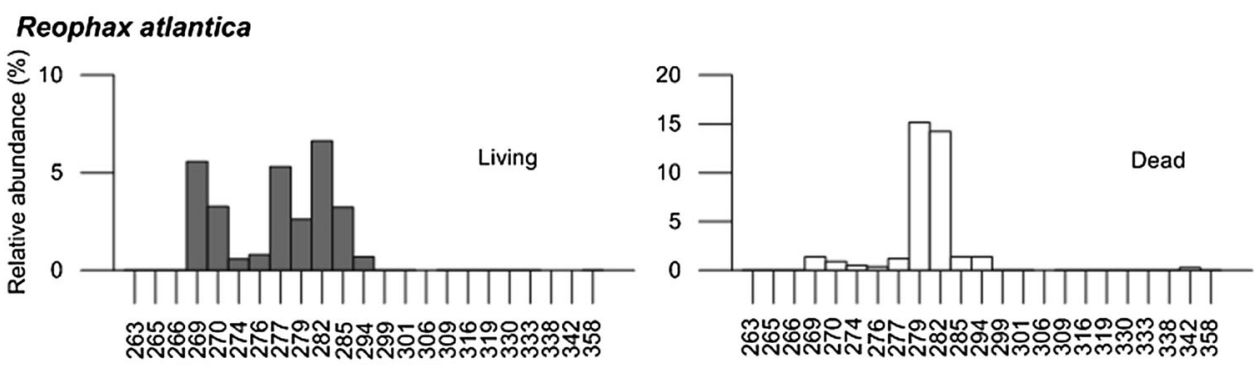

Reophax fusiformis
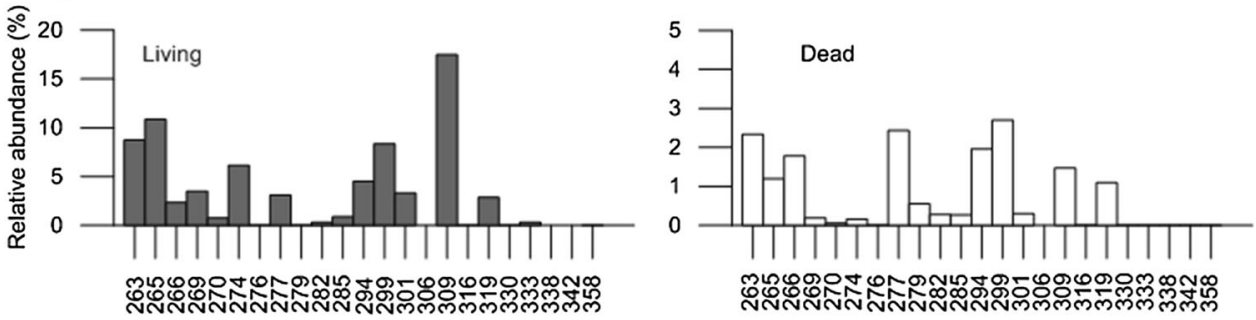

\section{Reophax guttifer}
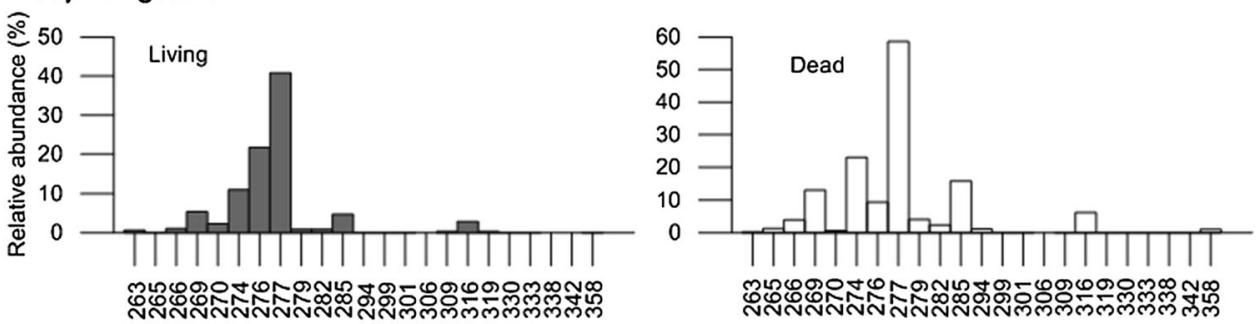

\section{Reophax spp.}
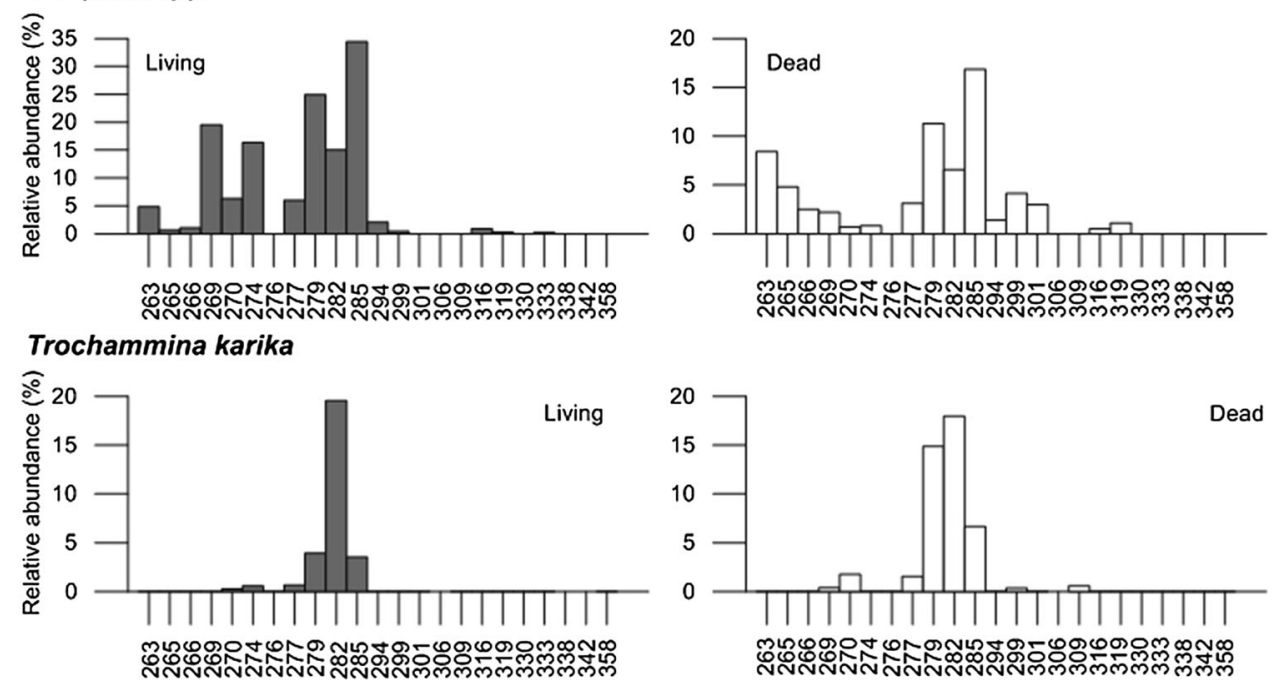

possible exception, seem not to be ruled by different temperatures or salinities. The sediment at the sampling stations is dominated by clay and silt except stations 338 and 342. Those stations containing very few living foraminifera are the sampling time, and it was not possible to carry out quantitative robust analysis of these two stations. This was feasible with the dead fauna; however, the stations do not differ with regard to fauna from stations dominated by clay and silt (Fig. 3). The three living assemblages are found within three partially different water depth intervals; 3000-3700 m (LFA1), 1300-3700 m (LFA2), and 300-1200 m (LFA3). Furthermore, the TOC content also show partial differences between the three living fauna assemblages. LFA1 is characterized by a TOC content from 0.9 to $1.4 \%$, whereas LFA2 show $0.3-0.7 \%$ and LFA3 $0.7-1.3 \%$ (Fig. 2). The content of TOC in the sediments of the Arctic Ocean does usually not reflect the primary production of the water masses due to the large input of terrestrial organic from the surrounding shelf and coastal seas to the Arctic Ocean (e.g., [39, 40]); however, 
we chose to display these values as part of the other environmental parameters for each foraminiferal assemblage. The first living fauna assemblage 1 (LFA1) is found in the Nansen Basin in water depths from ca. 3000 to $3700 \mathrm{~m}$ and an average TOC content of ca. $1 \%$. The most abundant species I. tumidula has previously been found at shallower water depths between 1500 and $3000 \mathrm{~m}$ in seasonally ice-free areas and even shallower under permanent ice cover by Wollenburg and Mackensen [43], yet its current occurrence is within seasonally ice-free areas as well (Figs. 2, 5a). It is important to note that the current study investigated a different size fraction than Wollenburg and Mackensen [43]. The latter investigated both the $63-125$ and $>125 \mu \mathrm{m}$ size fractions using $>125 \mathrm{~mm}$ size fraction for discussing the living foraminifera. Hence, direct comparisons of the $>100 \mu \mathrm{m}$ size fraction (this study) may not be robust. The other frequent species $S$. horvarthi was reported by Wollenburg and Mackensen [43] as only occurring in permanent ice covered areas and below $2700 \mathrm{~m}$.

LFA2 is found on Lomonosov Ridge, Alpha Ridge, and in the Nansen Basin in water depths from ca 1300 to $3700 \mathrm{~m}$. The average TOC content is ca. $0.6 \%$. LFA2 is also dominated by I. tumidula as LFA1, yet in LFA2 $I$. tumidula dominates together with $O$. tener and $S$. horvarthi. These findings of E. tumidulus and $S$. horvathi in LFA2 are in accordance with the findings by Wollenburg and Mackensen [43] as the shallow stations are under permanent ice cover and the deepest stations are within seasonally ice-free areas in the Nansen Basin (Figs. 2, 5a). Wollenburg and Mackensen [43] have observed the additional frequent species $O$. tener in nearly the same water depths as the current fauna assemblage. They assumed that $O$. tener is better adapted to oligotrophic conditions than $I$. tumidula, and food availability and competition seemed to be ruling the occurrence and frequency of $O$. tener [43]. The current study may also seem to indicate this as the stations of LFA2 contain slightly lower values of TOC than LFA1. Wollenburg and Mackensen [43] found that in general the living foraminiferal assemblages in the Arctic Ocean to be ruled by food availability and competition for food.

The last living fauna assemblage (LFA3) is confined to the seasonally ice-free Kara Sea continental margin (300-1200 m water depth) showing an average TOC value of ca. $1.0 \%$. One station shows relatively warmer bottom water temperatures (St. 269) than the others in LFA3 (Table 1), yet the fauna does not differ from the other colder stations (Appendix 1). LFA3 is dominated by agglutinated species, namely several Reophax species. The Reophax species are generally found in many different environments; however, they belong to a morphogroup (C1 cf. [23]) that is mainly found in marginal marine and shelf to upper slope marine environments [23]. This is in accordance with the current study, where the Reophax species are found on the shelf and upper slope (Fig. 5a). The calcareous species $C$. neoteretis, E. nipponica, and $I$. helenae are also found living in this assemblage. The same assemblage is also found living in the adjoining Barents Sea in seasonally ice-free areas. Here, $C$. neoteretis is linked to inflow of cooled Atlantic water [41]. It has also been found to thrive in areas with pulses of fresh phytodetritus [10]. E. nipponica has been characterized as a "warm" species [11]; however, it is morphologically very similar to Alabaminella weddellensis. This species has a wide temperature range, but it is similar to $C$. neoteretis preferring pulses of fresh phytodetritus [10]. I. helenae and Islandiella norcross (not differentiated as individual species) have also been linked to the sea ice margin together with in the Barents Sea where there is a high food supply [11]. Hence, this fauna assemblage is most probably ruled by the high food supply facilitated by nearby marginal ice zones and the associated high biological productivity [32].

\section{Dead vs living fauna assemblages}

The three dead fauna assemblages are also found within three partially different water depth intervals; 1300-3400 m (DFA1), 3100-4400 m (DFA2), and 300-1200 m (DFA3). The TOC values also differ somewhat between the assemblages. They are on average $0.3 \%$ (DFA1), $4.4 \%$ (DFA2), and $1.0 \%$ (DFA3).

The first dead fauna assemblage (DFA1) is found on the Lomonosov Ridge and Alpha Ridge, and is characterized by $I$. tumidula and $O$. tener in addition to $C$. wuellerstorfi (Fig. 5b; Appendix 1). I. tumidula and O. tener are also found in the living fauna assemblage (LFA2) in these areas except $S$. horvathi is reduced and $C$. wuellerstorfi is more prominent in the dead assemblage than in the living one. This can be due to the time of sampling (August and September 2007) which represents a snapshot of the yearlong assemblage. It could also be due to reworking and accumulation of dead $C$. wuellerstorfi.

In Amundsen Basin and Nansen Basin, the dead fauna assemblage 2 (DFA2) consists of S. horvathi and I. tumidula which are found in the two living fauna assemblages from these basins (LFA1, LFA2). The abundances of the most frequent species differ though between dead and living fauna assemblages resulting in different clusters. The abundance of T. frigida has increased in the dead fauna assemblage compared to the living assemblages making it one of the most frequent species in DFA2. This species has been found living found together with S. horvathi and I. tumidula in low productivity areas in the Arctic Ocean where it is believed to be influenced by food availability and competition [43]. Several different Aschemonella species also occur in higher numbers 
dead than living in the Amundsen Basin and Nansen Basin. These "primitive" species were also found living by Wollenburg and Mackensen [43] in permanently ice covered oligotrophic areas below depths of $3000 \mathrm{~m}$ that is in accordance with the current study.

The last dead fauna assemblage 3 (DFA3) is restricted to the Kara Sea continental margin (Fig. 5b) and encompasses the same stations as LFA3 (except station 276 which is an outlier in the living fauna assemblages). The difference between DFA3 and LFA3 is that the calcareous $C$. neoteretis is now the most frequent species, and the Reophax species are second. This is probable due to the low preservation potential of agglutinated species when dead (e.g., [7]). When comparing DFA3 and LFA3, P. aurantiaca appears more frequently in the dead fauna assemblage compared to the living fauna assemblage. This species has been found living in the Arctic Ocean in permanently ice covered areas in water depths from 1000 to $4000 \mathrm{~m}$ [43]. The current results are from seasonally ice-free areas and water depths from 1200 to $300 \mathrm{~m}$ water depth. $P$. aurantiaca was associated with local increased primary production in the Peru Trench [27] which could explain its presence on the Kara Sea continental margin with a higher primary production.

\section{Conclusions}

Twenty-three samples from the Arctic Ocean and Kara Sea continental margin have been investigated with regard to living (stained) and dead (unstained) benthic foraminifera. A high abundance of well-preserved dead benthic foraminifera and a relatively high number of living benthic foraminifera have been found. Using Q-mode cluster analysis of living and dead benthic foraminifera, three living and three dead benthic foraminiferal fauna assemblages have been identified. The different assemblages are not distinguished by different water mass temperatures nor salinities but probably food supply (cf. [43, 44]). In the seasonally ice-free Nansen Basin between ca. 3000 and $3700 \mathrm{~m}$ water depth, the I. tumidula-S. horvarthi assemblage (LFA1) has been observed. On the permanently ice covered Lomonosov Ridge and Alpha Ridge in addition to the seasonally ice-free Nansen Basin, the assemblage changes to the I. tumidula-O. tener-S. horvarthi assemblage (LFA2). The seasonally ice-free and relatively shallow Kara Sea continental margin (300-1200 m water depth) is characterized by a living fauna assemblage (LFA3) consisting of agglutinated Reophax species in addition to the calcareous species $C$. neoteretis, E. nipponica, and I. helenae. This fauna assemblage probably reflects a high food supply associated with the sea ice margin.

The dead assemblages (DFA1 and DFA2) reflect the living assemblages from Alpha Ridge, Lomonosov Ridge and Nansen Basin with assemblages characterized by $I$. tumidula, O. tener and $S$. horvathi. This suggests that there is a good potential for robust paleoenvironmental reconstruction from Alpha Ridge, Lomonosov Ridge and Nansen Basin. The dead fauna assemblage (DFA3) from the Kara Sea continental margin differs from the corresponding living assemblage (LFA3) by showing less agglutinated specimens and is dominated by $C$. neoteretis. However, there is also a relatively good potential for reconstructing paleoenvironmental changes from the Kara Sea continental margin, when it is taken into account that the agglutinated species are not well preserved in the dead assemblages.

Acknowledgments Sincere thanks are extended to Robert Spielhagen who supplied the surface sediment samples, the members of the geoscientific-working group sailing the ARK-XXII/2 expedition in addition to Captain Schwarze and his crew on RV "Polarstern". This study is a contribution to the IPY project "Arctic Natural Climate and Environmental Changes and Human Adaption: From Science to Public Awareness" (SciencePub) funded by the Norwegian Research Council, UiT-The Arctic University of Norway and the Norwegian Polar Institute. Sergei Korsun and his research group aided and assisted with the benthic foraminiferal taxonomy and analysis. Two anonymous reviewers helped improve the manuscript. To these institutions and persons, we offer our sincere thanks.

\section{Appendix 1}

See Tables 3 and 4 .

Table 3 Living (stained) foraminiferal abundances (>1\%)

\begin{tabular}{|c|c|c|c|c|c|c|c|c|c|c|c|c|c|}
\hline Station & 263 & 265 & 266 & 269 & 270 & 274 & 276 & 277 & 279 & 282 & 285 & 294 & 299 \\
\hline Adercotryma glomerata & 0.3 & 0.3 & 16.3 & 0.2 & 0.0 & 0.4 & 0.0 & 2.4 & 4.7 & 5.7 & 1.2 & 3.5 & 0.0 \\
\hline Adercotryma abyssorum & 0.6 & 0.0 & 0.0 & 0.7 & 0.0 & 2.9 & 0.0 & 14.9 & 0.0 & 0.9 & 1.5 & 2.8 & 0.9 \\
\hline Aschemonella sp. 1 & 3.6 & 3.9 & 0.0 & 0.5 & 0.0 & 0.0 & 0.0 & 0.0 & 0.0 & 0.0 & 0.0 & 1.4 & 0.0 \\
\hline Aschemonella sp. 2 & 0.0 & 0.3 & 0.0 & 0.0 & 0.0 & 0.6 & 0.0 & 0.0 & 0.0 & 0.3 & 0.0 & 7.6 & 0.0 \\
\hline Aschemonella sp. 3 & 8.7 & 0.0 & 0.0 & 0.0 & 0.0 & 0.0 & 0.0 & 0.0 & 0.0 & 0.0 & 0.0 & 0.0 & 0.0 \\
\hline Buccella frigida & 0.0 & 0.0 & 0.0 & 1.6 & 1.5 & 0.0 & 0.0 & 0.0 & 4.2 & 0.3 & 1.2 & 0.0 & 0.0 \\
\hline Buccella tenerrima & 0.0 & 0.0 & 0.0 & 0.0 & 0.0 & 0.0 & 0.0 & 0.0 & 5.8 & 0.0 & 0.0 & 0.0 & 0.0 \\
\hline Cassidulina laevigata & 0.0 & 0.0 & 0.0 & 0.0 & 0.3 & 0.0 & 4.0 & 0.0 & 0.0 & 0.0 & 0.0 & 0.0 & 0.0 \\
\hline
\end{tabular}


Table 3 continued

\begin{tabular}{|c|c|c|c|c|c|c|c|c|c|c|c|c|c|}
\hline Station & 263 & 265 & 266 & 269 & 270 & 274 & 276 & 277 & 279 & 282 & 285 & 294 & 299 \\
\hline Cassidulina neoteretis & 0.0 & 0.0 & 0.0 & 5.6 & 18.8 & 11.0 & 40.3 & 1.0 & 0.3 & 0.0 & 4.7 & 0.0 & 0.0 \\
\hline Cassidulina reniforme & 0.0 & 0.0 & 0.0 & 1.2 & 3.0 & 0.0 & 3.2 & 0.5 & 1.0 & 0.6 & 2.6 & 0.0 & 0.0 \\
\hline Cibicides lobatulus & 0.0 & 0.0 & 3.7 & 0.0 & 0.3 & 0.0 & 0.0 & 0.0 & 0.0 & 0.0 & 0.0 & 0.0 & 0.0 \\
\hline Cibicides wuellerstorfi & 0.0 & 0.0 & 0.0 & 0.0 & 0.3 & 0.2 & 0.0 & 0.0 & 0.0 & 0.0 & 0.0 & 0.7 & 0.0 \\
\hline Deuterammina grisea & 0.6 & 1.3 & 0.0 & 0.0 & 0.0 & 0.0 & 0.0 & 0.3 & 0.0 & 0.6 & 0.0 & 0.3 & 2.6 \\
\hline Elphidium excavatum f. clavata & 0.0 & 0.0 & 0.0 & 0.0 & 1.0 & 0.2 & 0.0 & 0.0 & 6.6 & 5.1 & 0.0 & 0.0 & 0.0 \\
\hline Epistominella arctica & 0.6 & 0.0 & 0.0 & 0.5 & 0.0 & 0.8 & 2.4 & 0.3 & 1.0 & 0.6 & 0.0 & 2.1 & 0.9 \\
\hline Epistominella nipponica & 0.0 & 0.3 & 0.0 & 6.0 & 16.8 & 0.0 & 0.0 & 0.0 & 0.0 & 0.0 & 0.0 & 0.0 & 0.0 \\
\hline Haplophragmoides subglobosum & 0.0 & 0.0 & 2.3 & 0.7 & 0.5 & 0.6 & 4.8 & 0.3 & 0.0 & 0.0 & 0.0 & 0.0 & 0.0 \\
\hline Hippocrepinella hirudinea & 0.0 & 0.0 & 0.0 & 0.5 & 0.5 & 1.2 & 0.0 & 0.0 & 0.0 & 4.5 & 0.9 & 0.0 & 0.0 \\
\hline Hormosinella distans & 0.0 & 0.0 & 0.0 & 0.0 & 0.0 & 1.0 & 2.4 & 2.1 & 0.0 & 0.0 & 0.3 & 0.0 & 0.0 \\
\hline Ioanella tumidula & 25.3 & 34.2 & 39.0 & 0.0 & 0.0 & 0.6 & 0.0 & 0.2 & 0.0 & 0.0 & 0.0 & 38.2 & 68.3 \\
\hline Islandiella helenae & 0.0 & 0.0 & 0.0 & 4.4 & 7.5 & 2.9 & 0.0 & 0.0 & 0.3 & 0.0 & 6.5 & 0.0 & 0.0 \\
\hline Islandiella islandica & 0.0 & 0.0 & 0.0 & 0.9 & 10.1 & 0.8 & 0.0 & 0.0 & 0.5 & 0.6 & 0.0 & 0.0 & 0.0 \\
\hline Islandiella norcrossi & 0.0 & 0.0 & 0.0 & 0.5 & 1.3 & 0.0 & 6.5 & 0.0 & 0.3 & 0.0 & 0.3 & 0.0 & 0.0 \\
\hline Jaculella sp. & 14.8 & 5.9 & 0.7 & 4.2 & 0.5 & 4.6 & 0.0 & 0.9 & 0.8 & 4.8 & 0.9 & 1.4 & 0.0 \\
\hline Oridorsalis tener & 3.6 & 5.9 & 8.0 & 0.0 & 0.0 & 0.4 & 0.0 & 0.0 & 0.0 & 0.0 & 0.0 & 2.8 & 4.0 \\
\hline Psammosphaera fusca & 0.6 & 0.0 & 1.3 & 2.3 & 0.3 & 2.7 & 2.4 & 0.0 & 4.7 & 2.7 & 0.3 & 0.7 & 0.0 \\
\hline Pullenia bulloides & 0.0 & 0.0 & 0.0 & 3.7 & 1.8 & 1.5 & 0.8 & 0.5 & 0.3 & 0.3 & 2.6 & 0.0 & 0.0 \\
\hline Pyrgo rotalaria & 0.0 & 0.0 & 3.3 & 0.0 & 0.0 & 0.0 & 0.0 & 0.0 & 0.0 & 0.0 & 0.0 & 0.7 & 0.0 \\
\hline Quinqueloculina akneriana & 2.4 & 0.3 & 3.7 & 0.0 & 0.3 & 0.2 & 0.0 & 0.0 & 0.3 & 0.6 & 0.0 & 0.7 & 0.0 \\
\hline Reophax atlantica & 0.0 & 0.0 & 0.0 & 5.6 & 3.3 & 0.6 & 0.8 & 5.3 & 2.6 & 6.6 & 3.2 & 0.7 & 0.0 \\
\hline Reophax curtus & 0.0 & 0.0 & 0.0 & 0.2 & 0.0 & 0.0 & 0.0 & 0.0 & 3.1 & 3.0 & 3.5 & 0.0 & 0.0 \\
\hline Reophax fusiformis & 8.7 & 10.9 & 2.3 & 3.5 & 0.8 & 6.2 & 0.0 & 3.1 & 0.0 & 0.3 & 0.9 & 4.5 & 8.4 \\
\hline Reophax guttifer & 0.6 & 0.0 & 1.0 & 5.3 & 2.3 & 11.0 & 21.8 & 40.8 & 0.8 & 0.9 & 4.7 & 0.0 & 0.0 \\
\hline Reophax scorpiurus & 0.0 & 0.0 & 0.0 & 7.2 & 2.0 & 5.0 & 9.7 & 2.2 & 3.4 & 2.1 & 0.0 & 0.0 & 0.0 \\
\hline Reophax subfusiformis & 0.0 & 0.0 & 0.0 & 0.0 & 5.8 & 1.3 & 0.0 & 0.5 & 1.0 & 1.2 & 8.5 & 0.0 & 0.0 \\
\hline Reophax spp. & 4.8 & 0.7 & 1.0 & 19.5 & 6.3 & 16.3 & 0.0 & 6.0 & 24.9 & 15.1 & 34.4 & 2.1 & 0.4 \\
\hline Robertina arctica & 0.0 & 0.0 & 0.0 & 0.0 & 0.5 & 0.0 & 0.0 & 0.0 & 2.4 & 0.9 & 0.3 & 0.0 & 0.0 \\
\hline Saccamina sp. & 0.0 & 6.9 & 1.7 & 5.1 & 1.0 & 5.0 & 0.0 & 5.3 & 0.3 & 0.6 & 6.5 & 1.7 & 1.3 \\
\hline Saccamminidae spp. & 0.3 & 0.0 & 0.0 & 0.0 & 0.3 & 0.0 & 0.0 & 2.2 & 0.0 & 0.0 & 0.6 & 0.0 & 0.0 \\
\hline Sorosphaera sp. & 0.0 & 0.0 & 0.0 & 3.0 & 0.0 & 0.0 & 0.0 & 0.0 & 0.0 & 0.0 & 0.3 & 3.5 & 0.0 \\
\hline Spiroplectammina biformis & 0.0 & 0.0 & 0.0 & 0.0 & 0.0 & 0.2 & 0.0 & 0.0 & 7.1 & 0.9 & 0.0 & 0.0 & 0.0 \\
\hline Stetsonia horvathi & 17.5 & 25.7 & 2.0 & 0.0 & 0.0 & 1.0 & 0.0 & 0.0 & 0.3 & 0.0 & 0.0 & 13.2 & 11.0 \\
\hline Subreophax aduncus & 5.4 & 1.6 & 0.0 & 0.7 & 0.0 & 1.5 & 0.0 & 0.0 & 0.0 & 0.0 & 1.2 & 1.0 & 0.4 \\
\hline Triloculina frigida & 0.0 & 0.0 & 0.0 & 1.2 & 0.0 & 1.2 & 0.0 & 0.2 & 0.0 & 0.0 & 0.6 & 0.0 & 0.4 \\
\hline Triloculina trihedra & 0.0 & 0.0 & 3.3 & 2.8 & 2.3 & 1.2 & 0.0 & 0.0 & 7.1 & 1.2 & 1.5 & 0.0 & 0.0 \\
\hline Trochammina karika & 0.0 & 0.0 & 0.0 & 0.0 & 0.3 & 0.6 & 0.0 & 0.7 & 3.9 & 19.6 & 3.5 & 0.0 & 0.0 \\
\hline Trochamminella bullata & 0.0 & 0.0 & 1.0 & 1.9 & 0.3 & 3.5 & 0.0 & 0.2 & 1.3 & 2.1 & 2.1 & 0.0 & 0.0 \\
\hline Trochamminella lomonosoviensis & 0.0 & 0.0 & 0.0 & 1.4 & 0.5 & 6.0 & 0.0 & 0.0 & 0.0 & 0.0 & 0.0 & 0.0 & 0.0 \\
\hline No of specimens counted & 332 & 304 & 300 & 430 & 398 & 520 & 124 & 583 & 381 & 332 & 340 & 288 & 227 \\
\hline Specimens $/ 10 \mathrm{~cm}^{3}$ & 126 & 61 & 120 & 459 & 1274 & 173 & 124 & 466 & 254 & 177 & 680 & 154 & 130 \\
\hline Station & 301 & & 306 & 309 & 316 & \multicolumn{2}{|c|}{319} & 330 & 333 & \multicolumn{2}{|c|}{338} & 342 & 358 \\
\hline Adercotryma glomerata & 0.0 & & $\mathrm{Na}$ & 0.0 & 1.1 & \multicolumn{2}{|c|}{1.4} & 0.0 & 0.0 & \multicolumn{2}{|c|}{$\mathrm{Na}$} & $\mathrm{Na}$ & 4.1 \\
\hline Adercotryma abyssorum & 2.2 & & $\mathrm{Na}$ & 0.0 & 0.0 & \multicolumn{2}{|c|}{0.6} & 0.0 & 0.0 & \multicolumn{2}{|c|}{$\mathrm{Na}$} & $\mathrm{Na}$ & 0.0 \\
\hline Aschemonella sp. 1 & 0.0 & & $\mathrm{Na}$ & 4.4 & 0.0 & \multicolumn{2}{|c|}{0.0} & 0.0 & 0.2 & \multicolumn{2}{|c|}{$\mathrm{Na}$} & $\mathrm{Na}$ & 0.0 \\
\hline Aschemonella sp. 2 & 0.0 & & $\mathrm{Na}$ & 24.6 & 0.0 & \multicolumn{2}{|c|}{0.0} & 0.0 & 0.0 & \multicolumn{2}{|c|}{$\mathrm{Na}$} & $\mathrm{Na}$ & 0.0 \\
\hline
\end{tabular}


Table 3 continued

\begin{tabular}{|c|c|c|c|c|c|c|c|c|c|c|}
\hline Station & 301 & 306 & 309 & 316 & 319 & 330 & 333 & 338 & 342 & 358 \\
\hline Aschemonella sp. 3 & 0.0 & $\mathrm{Na}$ & 2.2 & 0.0 & 0.0 & 0.0 & 0.0 & $\mathrm{Na}$ & $\mathrm{Na}$ & 0.0 \\
\hline Buccella frigida & 0.0 & $\mathrm{Na}$ & 0.2 & 0.0 & 0.0 & 0.0 & 0.0 & $\mathrm{Na}$ & $\mathrm{Na}$ & 0.0 \\
\hline Buccella tenerrima & 0.0 & $\mathrm{Na}$ & 0.0 & 0.0 & 0.0 & 0.0 & 0.0 & $\mathrm{Na}$ & $\mathrm{Na}$ & 0.0 \\
\hline Cassidulina laevigata & 0.0 & $\mathrm{Na}$ & 0.0 & 0.0 & 0.0 & 0.0 & 0.0 & $\mathrm{Na}$ & $\mathrm{Na}$ & 0.0 \\
\hline Cassidulina neoteretis & 0.0 & $\mathrm{Na}$ & 0.0 & 0.6 & 0.0 & 0.0 & 0.0 & $\mathrm{Na}$ & $\mathrm{Na}$ & 0.0 \\
\hline Cassidulina reniforme & 0.0 & $\mathrm{Na}$ & 0.5 & 0.0 & 0.0 & 0.0 & 0.0 & $\mathrm{Na}$ & $\mathrm{Na}$ & 0.0 \\
\hline Cibicides lobatulus & 0.0 & $\mathrm{Na}$ & 0.0 & 0.0 & 0.0 & 0.0 & 0.0 & $\mathrm{Na}$ & $\mathrm{Na}$ & 0.0 \\
\hline Cibicides wuellerstorfi & 0.0 & $\mathrm{Na}$ & 0.0 & 0.3 & 4.9 & 0.7 & 0.0 & $\mathrm{Na}$ & $\mathrm{Na}$ & 0.5 \\
\hline Deuterammina grisea & 1.3 & $\mathrm{Na}$ & 0.0 & 0.0 & 0.0 & 0.0 & 0.0 & $\mathrm{Na}$ & $\mathrm{Na}$ & 0.0 \\
\hline Elphidium excavatum f. clavata & 0.0 & $\mathrm{Na}$ & 0.2 & 0.0 & 0.0 & 0.0 & 0.0 & $\mathrm{Na}$ & $\mathrm{Na}$ & 0.0 \\
\hline Epistominella arctica & 2.2 & $\mathrm{Na}$ & 0.2 & 4.6 & 6.0 & 7.1 & 1.7 & $\mathrm{Na}$ & $\mathrm{Na}$ & 0.0 \\
\hline Epistominella nipponica & 0.0 & $\mathrm{Na}$ & 0.0 & 0.0 & 0.0 & 0.0 & 0.0 & $\mathrm{Na}$ & $\mathrm{Na}$ & 0.0 \\
\hline Eponides tumidulus & 65.4 & $\mathrm{Na}$ & 0.5 & 59.9 & 66.9 & 67.9 & 47.1 & $\mathrm{Na}$ & $\mathrm{Na}$ & 76.3 \\
\hline Haplophragmoides subglobosum & 0.0 & $\mathrm{Na}$ & 0.0 & 0.0 & 0.0 & 0.0 & 0.0 & $\mathrm{Na}$ & $\mathrm{Na}$ & 0.0 \\
\hline Hippocrepinella hirudinea & 0.0 & $\mathrm{Na}$ & 0.0 & 0.0 & 0.0 & 0.0 & 0.0 & $\mathrm{Na}$ & $\mathrm{Na}$ & 0.0 \\
\hline Islandiella helenae & 0.0 & $\mathrm{Na}$ & 0.0 & 2.0 & 0.0 & 0.0 & 0.0 & $\mathrm{Na}$ & $\mathrm{Na}$ & 0.0 \\
\hline Islandiella islandica & 0.0 & $\mathrm{Na}$ & 0.0 & 0.0 & 0.0 & 0.0 & 0.0 & $\mathrm{Na}$ & $\mathrm{Na}$ & 0.0 \\
\hline Islandiella norcrossi & 0.0 & $\mathrm{Na}$ & 0.0 & 0.0 & 0.0 & 0.0 & 0.0 & $\mathrm{Na}$ & $\mathrm{Na}$ & 0.0 \\
\hline Jaculella sp. & 0.0 & $\mathrm{Na}$ & 6.9 & 0.0 & 0.0 & 0.0 & 0.0 & $\mathrm{Na}$ & $\mathrm{Na}$ & 0.0 \\
\hline Oridorsalis tener & 4.9 & $\mathrm{Na}$ & 0.0 & 15.5 & 2.0 & 22.9 & 48.1 & $\mathrm{Na}$ & $\mathrm{Na}$ & 8.8 \\
\hline Psammosphaera fusca & 0.0 & $\mathrm{Na}$ & 4.7 & 0.0 & 1.4 & 0.0 & 0.0 & $\mathrm{Na}$ & $\mathrm{Na}$ & 0.0 \\
\hline Pullenia bulloides & 0.0 & $\mathrm{Na}$ & 0.0 & 0.0 & 0.0 & 0.0 & 0.0 & $\mathrm{Na}$ & $\mathrm{Na}$ & 0.0 \\
\hline Pyrgo rotalaria & 0.0 & $\mathrm{Na}$ & 0.0 & 0.0 & 0.0 & 0.0 & 0.0 & $\mathrm{Na}$ & $\mathrm{Na}$ & 0.0 \\
\hline Quinqueloculina akneriana & 0.0 & $\mathrm{Na}$ & 0.2 & 4.6 & 7.7 & 0.0 & 1.2 & $\mathrm{Na}$ & $\mathrm{Na}$ & 2.6 \\
\hline Reophax curtus & 0.0 & $\mathrm{Na}$ & 0.0 & 0.0 & 0.0 & 0.0 & 0.0 & $\mathrm{Na}$ & $\mathrm{Na}$ & 0.0 \\
\hline Reophax distans & 0.0 & $\mathrm{Na}$ & 0.0 & 0.0 & 0.0 & 0.0 & 0.0 & $\mathrm{Na}$ & $\mathrm{Na}$ & 0.0 \\
\hline Reophax fusiformis & 3.3 & $\mathrm{Na}$ & 17.5 & 0.0 & 2.9 & 0.0 & 0.3 & $\mathrm{Na}$ & $\mathrm{Na}$ & 0.0 \\
\hline Reophax guttifer & 0.0 & $\mathrm{Na}$ & 0.2 & 2.9 & 0.3 & 0.0 & 0.0 & $\mathrm{Na}$ & $\mathrm{Na}$ & 0.0 \\
\hline Reophax scorpiurus & 0.0 & $\mathrm{Na}$ & 0.0 & 0.0 & 0.0 & 0.0 & 0.0 & $\mathrm{Na}$ & $\mathrm{Na}$ & 0.0 \\
\hline Reophax subfusiformis & 0.0 & $\mathrm{Na}$ & 0.0 & 0.0 & 0.0 & 0.0 & 0.0 & $\mathrm{Na}$ & $\mathrm{Na}$ & 0.0 \\
\hline Reophax spp. & 0.0 & $\mathrm{Na}$ & 0.0 & 0.9 & 0.3 & 0.0 & 0.2 & $\mathrm{Na}$ & $\mathrm{Na}$ & 0.0 \\
\hline Robertina arctica & 0.0 & $\mathrm{Na}$ & 0.0 & 0.0 & 0.3 & 0.0 & 0.0 & $\mathrm{Na}$ & $\mathrm{Na}$ & 0.0 \\
\hline Saccaminna atlantica & 0.0 & $\mathrm{Na}$ & 0.0 & 0.0 & 0.0 & 0.0 & 0.0 & $\mathrm{Na}$ & $\mathrm{Na}$ & 0.0 \\
\hline Saccamina sp. & 1.3 & $\mathrm{Na}$ & 10.1 & 0.0 & 2.3 & 0.0 & 0.2 & $\mathrm{Na}$ & $\mathrm{Na}$ & 2.1 \\
\hline Saccamminidae spp. & 0.0 & $\mathrm{Na}$ & 0.0 & 0.0 & 0.0 & 0.0 & 0.0 & $\mathrm{Na}$ & $\mathrm{Na}$ & 0.0 \\
\hline Sorosphaera sp. & 0.0 & $\mathrm{Na}$ & 0.0 & 0.0 & 0.0 & 0.0 & 0.0 & $\mathrm{Na}$ & $\mathrm{Na}$ & 0.0 \\
\hline Spiroplectammina biformis & 0.0 & $\mathrm{Na}$ & 0.0 & 0.0 & 0.0 & 0.0 & 0.0 & $\mathrm{Na}$ & $\mathrm{Na}$ & 0.0 \\
\hline Stetsonia horvathi & 12.0 & $\mathrm{Na}$ & 9.1 & 2.6 & 0.3 & 0.0 & 0.0 & $\mathrm{Na}$ & $\mathrm{Na}$ & 0.0 \\
\hline Subreophax aduncus & 0.0 & $\mathrm{Na}$ & 0.0 & 0.0 & 0.0 & 0.0 & 0.0 & $\mathrm{Na}$ & $\mathrm{Na}$ & 0.0 \\
\hline Triloculina frigida & 3.5 & $\mathrm{Na}$ & 0.0 & 0.0 & 0.3 & 0.0 & 0.3 & $\mathrm{Na}$ & $\mathrm{Na}$ & 0.0 \\
\hline Triloculina trihedra & 0.0 & $\mathrm{Na}$ & 0.0 & 0.0 & 0.0 & 0.0 & 0.0 & $\mathrm{Na}$ & $\mathrm{Na}$ & 0.0 \\
\hline Trochammina karika & 0.0 & $\mathrm{Na}$ & 0.0 & 0.0 & 0.0 & 0.0 & 0.0 & $\mathrm{Na}$ & $\mathrm{Na}$ & 0.0 \\
\hline Trochamminella bullata & 0.0 & $\mathrm{Na}$ & 0.0 & 0.0 & 0.0 & 0.0 & 0.0 & $\mathrm{Na}$ & $\mathrm{Na}$ & 0.0 \\
\hline Trochamminella lomonosoviensis & 0.0 & $\mathrm{Na}$ & 0.0 & 0.0 & 0.0 & 0.0 & 0.0 & $\mathrm{Na}$ & $\mathrm{Na}$ & 0.0 \\
\hline No of specimens counted & 451 & 1 & 406 & 349 & 350 & 140 & 582 & 8 & 0 & 194 \\
\hline Specimens $/ 10 \mathrm{~cm}^{3}$ & 212 & $\mathrm{Na}$ & 65 & 465 & 140 & 187 & 111 & $\mathrm{Na}$ & $\mathrm{Na}$ & 259 \\
\hline
\end{tabular}

$\mathrm{Na}$ not applicable due to too few specimens 


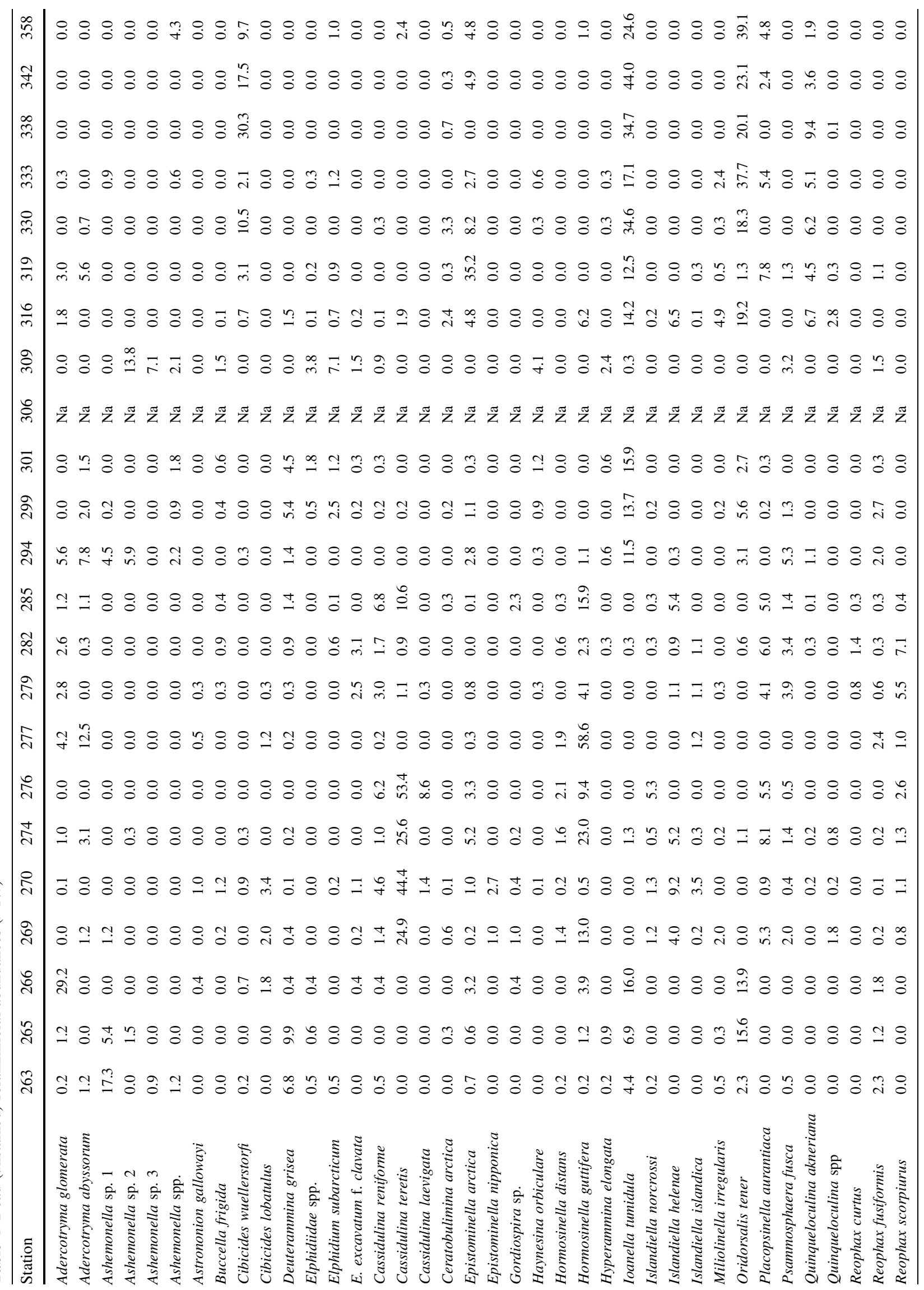




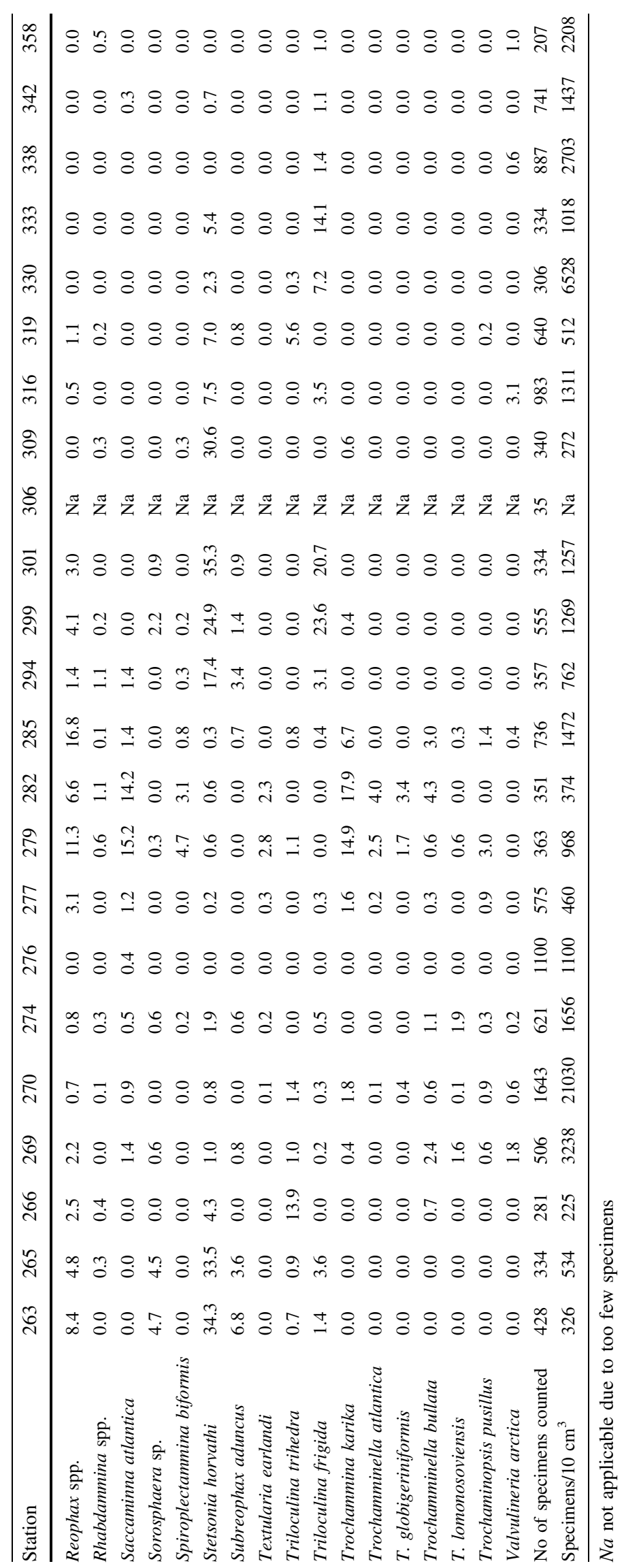




\section{Appendix 2}

The foraminiferal species are listed alphabetically by genus names. Aschemonellinae has been placed in the order Foraminiferida and not in the class Xenophyophorea. Otherwise, the genus names follow Ellis and Messina (1940-1978) and Loeblich and Tappan (1987)

Species list

Adercotryma glomerata (Brady, 1878)

Adercotryma abyssorum Saidova, 1975

Aschemonella spp. Brady, 1879

Buccella frigida (Cushman, 1921)

Cassidulina laevigata d'Orbigny, 1826

Cassidulina neoteretis Seidenkrantz, 1995

Cassidulina reniforme Nørvang, 1945

Ceratobulimina arctica Green, 1959

Cibicides lobatulus (Walker and Jacob, 1798)

Cibicides wuellerstorfi (Schwager, 1866)

Deuterammina grisea Earland, 1934

Elphidiidae spp. Galloway, 1933

Elphidium excavatum (Terquem) f. clavata (Cushman, 1944)

Elphidium hallandense Brotzen, 1943

Epistominella arctica Green, 1960

Epistominella nipponica (Kuwano, 1962)

Ioanella tumidula (Brady, 1884)

Haynesina orbiculare (Brady, 1881)

Hyperammina elongata Brady, 1878

Islandiella norcrossi (Cushman, 1933)

Islandiella helenae Feyling-Hanssen and Buzas, 1976.

Oridorsalis tener (Brady, 1884)

Placopsilinella aurantiaca Earland, 1934

Psammosphaera fusca Schulze, 1875

Quinqueloculina akneriana d'Orbigny, 1846

Saccaminna atlantica (Cushman, 1944)

Reophax curtus Cushman, 1920

Hormosinella distans (Brady, 1881)

Reophax fusiformis Williamson, 1858

Hormosinella guttifera (Brady, 1881)

Reophax scorpiurus de Montfort, 1808

Reophax spp. de Montfort, 1808

Rhabdammina spp Sars, 1869

Sorosphaera sp. Brady, 1879

Spiroplectammina biformis (Parker and Jones, 1865)

Stetsonia horvathi Green, 1960

Subreophax aduncus Brady, 1882

Trochammina karika Shchedrina, 1946

Trochamminella atlantica Parker, 1952

Trochamminella globigeriniformis (Parker and Jones, 1865)

Trochamminella bullata Høglund, 1947

Textularia earlandi Parker, 1952
Triloculina trihedra Loeblich and Tappan, 1953

Triloculina frigida Lagoe, 1977

Valvulineria arctica Green, 1959

\section{References}

1. Aagaard K, Foldvik A, Hillman SR (1987) The West Spitsbergen current: disposition, water mass transformation. J Geo Res 92:3778-3784

2. Bergsten H (1994) Recent benthic foraminifera of a transect from the North Pole to the Yermak Plateau, eastern central Arctic Ocean. Mar Geo 119:251-267

3. Beszczynska-Moeller A, Fahrbach E, Schauer U, Hansen E (2012) Variability in Atlantic water temperature, transport at the entrance to the Arctic Ocean, 1997-2010. Ices J Mar Sci 69:852-863

4. Chauhan T, Rasmussen TL, Noormets R, Jakobsson M, Hogan KA (2014) Glacial history, paleoceanography of the southern Yermak Plateau since 132 ka BP. Quat Sci Rev 92:155-169

5. Cronin TM, Smith SA, Eynaud F et al (2008) Quaternary paleoceanography of the central arctic based on integrated ocean drilling program arctic coring expedition 302 foraminiferal assemblages. Pal 23:118-133

6. Darby DA, Polyak L, Bauch HA (2006) Past glacial, interglacial conditions in the Arctic Ocean, marginal seas-a review. Prog Oce 71:129-144

7. Dijkstra N, Junttila J, Husum K, Carroll J, Hald M (2015) Natural variability of benthic foraminiferal assemblages, metal concentrations during the last 150 years in the Ingøydjupet trough, SW Barents Sea. Mar Mic 121:16-31

8. Ellis BE, Messina AR (1940-1978) Catalogue of foraminifera. American Museum of Natural History, New York

9. Fisher RA, Corbet AS, Williams CB (1943) The relationship between the number of species, the number of individuals in a random sample of an animal population. J Ani Ecol 12:42-58

10. Gooday AJ, Lambshead PJD (1989) Influence of seasonally deposited phytodetritus on benthic foraminiferal populations in the northeast Atlantic: the species response. Mar Ecol Prog Ser 58:53-67

11. Hald M, Steinsund PI (1996) Surface-sediment composition, sedimentary processes in the central Arctic Ocean along the Eurasian Continental Margin. In: Stein R, Ivanov GI, Levitan MA, Fahl K (eds) Surface-sediment composition and sedimentary processes in the central Arctic Ocean and along the Eurasian Continental Margin, Bremerhaven, pp 285-307

12. Hald M, Korsun S (1997) Distribution of modern benthic foraminifera from fjords of Svalbard, European Arctic. J For Res 27:101-122

13. Hammer $\varnothing$, Harper DAT, Ryan PD (2001) PAST: paleontological statistics software package for education, data analysis. Pal Elec 4:1-9

14. Hayek LAC, Buzas MA (1997) Surveying natural populations. Columbia, New York

15. Ishman SE, Foley KM (1996) Modern benthic foraminifer distribution in the Amerasian Basin, Arctic Ocean. Mic 42:206-220

16. Ishman SE, Polyak LV, Poore RZ (1996) Expanded record of quaternary oceanographic change: Amerasian Arctic Ocean. Geo 24:139-142

17. Jakobsson M, Lovlie R, Arnold EM et al (2001) Pleistocene stratigraphy, paleoenvironmental variation from Lomonosov Ridge sediments, central Arctic Ocean. Glob Plan Chan 31:1-22 
18. Jakobsson M (2002) Hypsometry and volume of the Arctic Ocean and its constituent seas. Geo, Geo, Geo 5:1-18

19. Jakobsson M, Macnab R, Mayer L et al (2008) An improved bathymetric portrayal of the Arctic Ocean: implications for ocean modeling, geological, geophysical, oceanographic analyses. Geo Res Let 35

20. Knudsen KL, Austin WEN (1996) Paleoceanography in the European Arctic margin during the last deglaciation. In: Andrews JT, Austin WEN, Bergsten H, Jennings AE (eds) Paleoceanography in the European Arctic margin during the last deglaciation, pp 7-11

21. Lagoe MB (1977) Recent benthic foraminifera from the central Arctic Ocean. J For Res 7(2):106-129

22. Loeblich AR, Tappan H (1987) Foraminiferal genera, their classification Van Nostr. Reinhold Co, New York

23. Murray JW, Alve E, Jones BW (2011) A new look at modern agglutinated benthic foraminiferal morphogroups: their value in palaeoecological interpretation. Pal Pal Pal 309(3-4):229-241

24. NSIDC http://nsidc org/data/seaice_index/

25. Osterman LE, Poore RZ, Foley KM (1999) Distribution of benthic foraminifers $(>125 \mu \mathrm{m})$ in the surface sediments of the Arctic Ocean. U.S Geol Surv Bul 2164:1-36

26. Rudels B (2015) Arctic Ocean circulation, processes, water masses: a description of observations, ideas with focus on the period prior to the international polar year 2007-2009. Prog Oce 132:22-67

27. Resig JM (1981) Biogeography of benthic foraminifera of the northern Nazca plate, adjacent continental margin. Geo Soc Ame Mem 154:619-666

28. Rudels B, Jones EP, Anderson LG, Kattner G (1994) The Polar Oceans, their role in shaping the global environment. In: Johannessen OM, Muench RD, Overland JE (eds) The Polar Oceans and their role in shaping the global environment, pp 33-46

29. Polyak L, Curry WB, Darby DA et al (2004) Contrasting glacial/ interglacial regimes in the western Arctic Ocean as exemplified by a sedimentary record from the Mendeleev Ridge. Pal Pal Pal 203:73-93

30. Saher M, Kristensen DK, Hald M, Korsun S, Jorgensen LL (2009) Benthic foraminifera assemblages in the central Barents Sea: an evaluation of the effect of combining live, total fauna studies in tracking environmental change. Nor J Geol 89:149-161

31. Saher M, Kristensen DK, Hald M et al (2012) Changes in distribution of calcareous benthic foraminifera in the central Barents
Sea between the periods $1965-1992$ and 2005-2006. Glob Plan Chan: 81-96

32. Sakshaug E, Skjoldal HR (1989) Life at the Ice Edge. Amb 18:60-67

33. Schauer U (2008) The expedition of the research vessel "Polarstern" to the Arctic in 2007 (ARK-XXII/2). Ber Pol Meer 579:1-264

34. Schauer U, Rudels B, Jones EP et al (2002) Confluence, redistribution of Atlantic water in the Nansen, Amundsen, Makarov basins. Ann Geo 20:257-273

35. Scott DB, Vilks G (1991) Benthic foraminifera in the surface sediments of the deep-sea Arctic Ocean. J For Res 21:20-38

36. Scott DB, Schell T, Rochon A, Blasco S (2008) Benthic foraminifera in the surface sediments of the Beaufort Shelf, slope, Beaufort Sea, Canada: applications, implications for past sea-ice conditions. J Mar Sys 74:840-863

37. Schröder-Adams CJ, Cole FE, Medioli FS et al (1990) Recent Arctic shelf foraminifera; seasonally ice covered vs perennially ice covered areas. J For Res 20:8-36

38. Shannon CE, Weaver W (1963) The mathematical theory of communication. University of Illinois Press, Champaign

39. Stein R, Grobe H, Wahsner M (1994) Organic carbon, carbonate, clay mineral distributions in eastern central Arctic Ocean surface sediments. Mar Geo 119:269-285

40. Stein R, Fahl K (2000) Holocene accumulation of organic carbon at the Laptev Sea continental margin (Arctic Ocean): sources, pathways, sinks. Geo-Mar Let 20:27-36

41. Steinsund PI (1994) Benthic foraminifera in the surface sediments of the Barents, Kara Seas: modern and late Quaternary applications. Dissertation, University of Troms $\varnothing$

42. Stroeve J, Holland MM, Meier W et al (2007) Arctic sea ice decline: Faster than forecast. Geo Res Let: 34

43. Wollenburg JE, Mackensen A (1998) Living benthic foraminifers from the central Arctic Ocean: faunal composition, standing stock, diversity. Mar Mic 34:153-185

44. Wollenburg JE, Kuhnt W (2000) The response of benthic foraminifers to carbon flux, primary production in the Arctic Ocean. Mar Mic 40:189-231

45. Wollenburg JE, Knies J, Mackensen A (2004) High-resolution paleoproductivity fluctuations during the past $24 \mathrm{kyr}$ as indicated by benthic foraminifera in the marginal Arctic Ocean. Pal Pal Pal 204:209-238 